\title{
VGluT3-Expressing CCK-Positive Basket Cells Construct Invaginating Synapses Enriched with Endocannabinoid Signaling Proteins in Particular Cortical and Cortex-Like Amygdaloid Regions of Mouse Brains
}

\author{
Yuki Omiya, ${ }^{1,2 \star}$ Motokazu Uchigashima, ${ }^{1 \star}$ Kohtarou Konno, ${ }^{1}$ Miwako Yamasaki, ${ }^{1}$ Taisuke Miyazaki, ${ }^{1}$ \\ Takayuki Yoshida, ${ }^{3}$ Ichiro Kusumi, ${ }^{2}$ and Masahiko Watanabe ${ }^{1}$ \\ Departments of ${ }^{1}$ Anatomy, ${ }^{2}$ Psychiatry, and ${ }^{3}$ Neuropharmacology, Hokkaido University Graduate School of Medicine, Sapporo 060-8638, Japan
}

Invaginating synapses in the basal amygdala are a unique type of GABAergic synapses equipped with molecular-anatomical organization specialized for 2-arachidonoylglycerol (2-AG)-mediated endocannabinoid signaling. Cholecystokinin (CCK)-positive basket cell terminals protrude into pyramidal cell somata and form invaginating synapses, where apposing presynaptic and postsynaptic elements are highly loaded with cannabinoid receptor $\mathrm{CB}_{1}$ or $2-\mathrm{AG}$ synthetic enzyme diacylglycerol lipase- $\alpha$ (DGL $\alpha$ ), respectively. The present study scrutinized their neurochemical and neuroanatomical phenotypes in adult mouse telencephalon. In the basal amygdala, vesicular glutamate transporter-3 (VGluT3) was transcribed in one-fourth of $\mathrm{CB}_{1}$-expressing GABAergic interneurons. The majority of VGluT3positive $\mathrm{CB}_{1}$-expressing basket cell terminals apposed DGL $\alpha$ clusters, whereas the majority of VGluT3-negative ones did not. Importantly, VGluT3-positive basket cell terminals selectively constructed invaginating synapses. $\mathrm{GABA}_{\mathrm{A}}$ receptors accumulated on the postsynaptic membrane of invaginating synapses, whereas metabotropic glutamate receptor- $5\left(\mathrm{mGluR}_{5}\right)$ was widely distributed on the somatodendritic surface of pyramidal cells. Moreover, $\mathrm{CCK}_{2}$ receptor $\left(\mathrm{CCK}_{2} \mathrm{R}\right)$ was highly transcribed in pyramidal cells. In cortical regions, pyramidal cells equipped with such VGluT3/CB $1 / \mathrm{DGL} \alpha$-accumulated invaginating synapses were found at variable frequencies depending on the subregions. Therefore, in addition to extreme proximity of $\mathrm{CB}_{1^{-}}$and $\mathrm{DGL} \alpha$-loaded presynaptic and postsynaptic elements, tripartite transmitter phenotype of GABA/glutamate/CCK is the common neurochemical feature of invaginating synapses, suggesting that glutamate, $\mathrm{CCK}$, or both can promote 2-AG synthesis through activating $\mathrm{G} \alpha_{\mathrm{q} / 11}$ protein-coupled $\mathrm{mGluR}_{5}$ and $\mathrm{CCK}_{2} \mathrm{R}$. These molecular configurations led us to hypothesize that invaginating synapses might be evolved to provide some specific mechanisms of induction, regulation, and cooperativity for 2-AG-mediated retrograde signaling in particular cortical and cortex-like amygdaloid regions.

Key words: amygdala; cannabinoid CB1 receptor; cerebral cortex; cholecystokinin-positive basket cell; invaginating synapse; sn-1specific diacylglycerol lipase

\section{Introduction}

Upon depolarization-induced $\left[\mathrm{Ca}^{2+}\right]_{\mathrm{i}}$ elevation (Kreitzer and Regehr, 2001; Ohno-Shosaku et al., 2001; Wilson and Nicoll, 2001), $\mathrm{G} \alpha_{\mathrm{q} / 11}$ protein-coupled receptor activation (Maejima et al., 2001), or both (Varma et al., 2001; Ohno-Shosaku et al., 2002; Hashimotodani et al., 2005; Maejima et al., 2005), endocan-

\footnotetext{
Received Nov. 13, 2014; revised Jan. 8, 2015; accepted Jan. 29, 2015.

Author contributions: M.U. and M.W. designed research; Y.O., M.U., K.K., M.Y., and T.Y. performed research; T.M. and I.K. contributed unpublished reagents/analytic tools; Y.O. and M.U. analyzed data; M.W. wrote the paper.

This work was supported by Ministry of Education, Culture, Sports, Science and Technology, Japan Grants-in-Aid for Scientific Research 19100005 to M.W. and 25830031 to M.U. We thank Prof. Masanobu Kano (University of Tokyo) for critical reading and helpful comments on this work.

The authors declare no competing financial interests.

*Y.O. and M.U. contributed equally to this work.

Correspondence should be addressed to Dr. Masahiko Watanabe, Department of Anatomy, Hokkaido University

School of Medicine, Sapporo 060-8638, Japan. E-mail: watamasa@med.hokudai.ac.jp.

DOI:10.1523/JNEUROSCI.4681-14.2015

Copyright $\odot 2015$ the authors $\quad 0270-6474 / 15 / 354215-14 \$ 15.00 / 0$
}

nabinoids (eCBs) are released from postsynaptic neurons, act retrogradely on presynaptic cannabinoid receptor- $1\left(\mathrm{CB}_{1}\right)$, and induce short- and long-term suppression of transmitter release (Hashimotodani et al., 2007a). This retrograde signaling is involved in various neural functions, such as learning and memory, analgesia, and neuroprotection (Kano et al., 2009). In the brain, 2-arachidonoylglycerol (2-AG) is the major eCB synthesized by $s n-1$ diacylglycerol lipase- $\alpha$ (DGL $\alpha$ ) (Mechoulam et al., 1995; Sugiura et al., 1995; Stella et al., 1997; Bisogno et al., 2003; Gao et al., 2010; Tanimura et al., 2010). 2-AG is degraded mainly by monoacylglycerol lipase (Dinh et al., 2002; Blankman et al., 2007; Schlosburg et al., 2010), which regulates the magnitude and spatiotemporal profiles of retrograde signaling (Gulyas et al., 2004; Hashimotodani et al., 2007b; Pan et al., 2009; Tanimura et al., 2012; Blankman and Cravatt, 2013).

In the cerebral cortex, hippocampus, and $\mathrm{BLA}, \mathrm{CB}_{1}$ is enriched in GABAergic terminals of CCK-positive basket cells that 
target pyramidal cell somata (Katona et al., 1999, 2001; Marsicano and Lutz, 1999; Tsou et al., 1999; Boder et al., 2005). In these cortical regions and cortex-like amygdala, DGL $\alpha$ is concentrated at dendritic spines forming excitatory synapses in pyramidal cells (Katona et al., 2006; Yoshida et al., 2006; Uchigashima et al., 2011), whereas $\mathrm{CB}_{1}$ is expressed weakly in excitatory terminals innervating pyramidal cell spines (Kawamura et al., 2006). Such a reciprocal molecular arrangement is likely to coordinate the induction of 2-AG-mediated retrograde suppression of excitation and inhibition (Kano et al., 2009). Against this prevailing scheme, we previously discovered a unique type of CCK-positive basket cell synapses in the basal amygdala (BA), termed invaginating synapses (Yoshida et al., 2011). High levels of DGL $\alpha$ and $\mathrm{CB}_{1}$ are characteristic of invaginating synapses, where $\mathrm{CB}_{1}$-expressing nerve terminals invaginate DGL $\alpha$-recruited pyramidal cell somata. In cortical regions, CCK-positive basket cells are classified into those expressing vesicular glutamate transporter-3 (VGluT3) or VIP (Somogyi et al., 2004; Klausberger and Somogyi, 2008); however, the type of basket cells that construct invaginating synapses is unclear. Moreover, although invaginating synapses are unique to the BA within the amygdala, it remains unknown whether they exist in cortical regions.

In the present study, we found that VGluT3-expressing CCKpositive basket cells exclusively formed invaginating synapses in the BA. The postsynaptic membrane of invaginating synapses expressed $\mathrm{GABA}_{\mathrm{A}}$ receptors, whereas metabotropic glutamate receptor-5 $\left(\mathrm{mGluR}_{5}\right)$ was widely expressed on the extrasynaptic somatodendritic surface. Pyramidal cells also expressed $\mathrm{CCK}_{2}$ receptor $\left(\mathrm{CCK}_{2} \mathrm{R}\right)$ mRNA richly. Furthermore, VGluT3/CB 1 DGL $\alpha$-accumulated invaginating synapses were richly formed in several cortical regions. These findings suggest that tripartite transmitter phenotype of GABA/glutamate/CCK is the common neurochemical feature of invaginating synapses in cortical regions and cortex-like amygdala, and that glutamate, CCK, or both promote retrograde suppression of transmitter release through activating their $\mathrm{G} \alpha_{\mathrm{q} / 11}$ protein-coupled receptors.

\section{Materials and Methods}

Animals and tissue sections. All animal experiments were performed according to the guidelines for the care and use of laboratory animals of Hokkaido University. Under deep pentobarbital anesthesia $(100 \mathrm{mg} / \mathrm{kg}$ of body weight, i.p.), male C57BL/6 mice at 2-4 months of age (adult) were fixed by transcardial perfusion with $4 \%$ PFA in $0.1 \mathrm{~m}$ phosphate buffer, $\mathrm{pH}$ 7.2, for immunofluorescence and in situ hybridization, and $4 \%$ PFA $/ 0.1 \%$ glutaraldehyde in $0.1 \mathrm{~m}$ phosphate buffer for immunoelectron microscopy. Microslicer sections (50 $\mu \mathrm{m}$ in thickness) were prepared for immunofluorescence and immunoelectron microscopy (VT1000S, Leica). For chromogenic in situ hybridization, brains were postfixed in the same fixative for $3 \mathrm{~d}$ at room temperature and used to prepare frozen sections $(50 \mu \mathrm{m})$ with a cryostat (CM1900, Leica). For fluorescence in situ hybridization (FISH), fresh frozen sections $(20 \mu \mathrm{m})$ were prepared using unfixed brains. Qualitative and quantitative data were obtained from two or three mice and pooled together.

In situ hybridization. We used the following fluorescein- or digoxigenin (DIG)-labeled riboprobes: mouse $\mathrm{CB}_{1}$ (121-1630, U22948), mouse preproCCK (124-411bp, accession number NM_031161), mouse CCK 2 R (206-1243, NM_007627), mouse 67 kDa glutamic acid decarboxylase (GAD67, 1035-2015; NM_008077), mouse VGluT1 (301-1680, BC054462), mouse, VGluT3 (22-945, NM_182959), and mouse preproVIP (155-683, NM_011702). Probe synthesis and in situ hybridization were performed following the protocol described previously (Yamasaki et al., 2010).

For immunohistochemical detection of DIG and fluorescein, sections were blocked with DIG blocking solution (TNT buffer containing 1\% blocking reagent [Roche Diagnostics] and 4\% normal sheep serum) for
Table 1. Primary antibodies used in the present study

\begin{tabular}{|c|c|c|c|c|}
\hline Molecule & Antigen (NCBI no.) & Host & Specificity & Reference/source \\
\hline CaMKII $\alpha$ & rat CaMKII $\alpha$ & Ms & IB & $\begin{array}{l}\text { Merck-Millipore (05-532, } \\
\text { clone } 6 \mathrm{G} 9 \text { ) }\end{array}$ \\
\hline $\mathrm{CB}_{1}$ & 443-473 (NM_007726) & $\mathrm{Rb}, \mathrm{GP}, \mathrm{Go}$ & $\mathrm{K} 0, \mathrm{IB}$ & Fukudome et al. (2004) \\
\hline $\mathrm{DGL} \alpha$ & 1003-1044 (NM_198114) & $\mathrm{Rb}, \mathrm{G}_{0}$ & $\mathrm{KO}, \mathrm{IB}$ & Yoshida et al. (2006) \\
\hline $\mathrm{GABA}_{\mathrm{A}} \mathrm{R} \alpha 1$ & 369-386 (NM_010250) & $\mathrm{Rb}$ & IB/HEK & Ichikawa et al. (2011) \\
\hline GluA2 & $847-863$ (X57498) & $\mathrm{Rb}$ & IB/KO & Yamazaki et al. (2010) \\
\hline MAP2 & 927-1104 (NM_008632) & Go & $a$ & Miura et al. (2006) \\
\hline mGluR $_{5}$ & 1144-1171 (D10891) & $\mathrm{Rb}, \mathrm{GP}$ & KO & Uchigashima et al. (2007) \\
\hline VGluT3 & 558-601 (AF510321) & $G P, G_{0}$ & IB & Somogyi et al. (2004) \\
\hline VIAAT & 75-87 (NM_031782) & Ms & & Synaptic Systems (1310011) \\
\hline VIP & porcine VIP & $\mathrm{Rb}$ & PT & Euro-Diagnostica (RB311) \\
\hline
\end{tabular}

Go, Goat polyclonal antibody; GP, guinea pig polyclonal antibody; HEK, immunoblot with transfected HEK293T cell lysates; IB, immunoblot with brain homogenates; K0, lack of immunohistochemical or immunoblot labeling in knockout mice; Ms, mouse monoclonal antibody; $\mathrm{PT}$, preabsorption test; $\mathrm{Rb}$, rabbit polyclonal antibody.

${ }^{a}$ The specificity of MAP2 antibody is supported by selective labeling of somatodendritic neuronal elements.

$30 \mathrm{~min}$, and $0.5 \%$ tyramide signal amplification (TSA) blocking reagent (PerkinElmer) in TNT buffer for $30 \mathrm{~min}$. Sections were incubated with either alkaline phosphatase-conjugated sheep anti-DIG (Roche Diagnostics, 1:500, $1.5 \mathrm{~h}$ ) for chromogenic detection or with peroxidaseconjugated anti-DIG (Roche Diagnostics; 1:1000, $1 \mathrm{~h}$ ) or anti-fluorescein antibody (Invitrogen; 1:1500, $1 \mathrm{~h}$ ) for fluorogenic detection. After two washes in TNT buffer for $15 \mathrm{~min}$ each, chromogenic detection was performed using nitro-blue tetrazolium and 5-bromo-4-chloro- $3^{\prime}$ indolyphosphate (Roche Diagnostics, 1:50) in detection buffer $(0.1 \mathrm{~m}$ Tris- $\mathrm{HCl}$, pH 9.5, $0.1 \mathrm{M} \mathrm{NaCl}$, and $50 \mathrm{mM} \mathrm{MgCl}_{2}$ ) for $12 \mathrm{~h}$. For doublelabeling FISH the first detection was performed with peroxidaseconjugated anti-fluorescein antibody followed by incubation with the FITC-TSA plus amplification kit (PerkinElmer). After inactivation of residual peroxidase activity by dipping sections in $1 \% \mathrm{H}_{2} \mathrm{O}_{2}$ for $30 \mathrm{~min}$, the second detection was performed by incubating sections in peroxidase-conjugated anti-DIG antibody, followed by incubation with the indocarbocyanine (Cy3)-TSA plus amplification kit (PerkinElmer). Images of chromogenic in situ hybridization were taken with a light microscope (BZ-9000; Keyence), and PlanApo $(4 \times / 0.20$ and $10 \times / 0.45)$ objective lenses (Nikon), whereas images of FISH were captured using confocal laser-scanning microscope equipped with a $\mathrm{HeNe} / \mathrm{Ar}$ laser, and PlanApo $(10 \times / 0.40)$ and PlanApo $(20 \times / 0.70)$ objective lenses (FV1000; Olympus). The specificity of hybridization signals with use of the above antisense riboprobes was tested by the lack of any significant labeling with use of their sense riboprobes.

$\mathrm{CB}_{1}$ mRNA- or preproCCK mRNA-positive cells were microscopically classified into strong and weak cells. Strong cells were defined as cells with fluorescent signals strong enough to fill up the nucleoplasm, whereas weak cells were defined as those with negative or translucent nucleoplasm. To assess the validity of this classification, we measured fluorescent intensity of $\mathrm{CB}_{1}$ mRNA using an ImageJ software (http://imagej.nih.gov/ij/). The mean fluorescent intensity in strong cells was 3.7 times higher than that in weak cells.

Antibodies. We used the following primary antibodies raised against the following molecules: $\mathrm{Ca}^{2+} /$ calmodulin-dependent kinase II $\alpha$ subunit $(\mathrm{CaMKII} \alpha), \mathrm{CB}_{1}, \mathrm{DGL} \alpha, \mathrm{GABA}_{\mathrm{A}}$ receptor $\alpha 1$ subunit $\left(\mathrm{GABA}_{\mathrm{A}} \mathrm{R} \alpha 1\right)$, AMPA receptor subunit GluA2, $\mathrm{mGluR}_{5}$, microtubule-associated protein 2 (MAP2), VGluT3, vesicular inhibitory amino acid transporter (VIAAT), and VIP. Information on the antigen sequence, host species, specificity, and source of these primary antibodies is summarized in Table 1.

Immunofluorescence. All immunohistochemical incubations were performed at room temperature. For immunofluorescence, microslicer sections were incubated successively with $10 \%$ normal donkey serum for 20 min, a mixture of primary antibodies overnight $(1 \mu \mathrm{g} / \mathrm{ml})$, and a mixture of Alexa405- Alexa488-, Cy3-, and Alexa647-labeled species-specific secondary antibodies for $2 \mathrm{~h}$ at a dilution of 1:200 (Invitrogen, Jackson ImmunoResearch Laboratories, Abcam). PBS with $0.1 \%$ Tween 20 was used as a dilution buffer. Images were taken with a confocal laserscanning microscope equipped with the $405,473,559$, and $647 \mathrm{~nm}$ diode 
laser lines and a PLAPON 60× OSC2 objective lens (NA: 1.4) (FV1200; Olympus).

Immunoelectron microscopy. For pre-embedding immunogold electron microscopy, microslicer sections were dipped in Blocking Solutions (Aurion) for $30 \mathrm{~min}$ and incubated overnight with primary antibodies diluted with $1 \%$ BSA/0.004\% saponin/PBS and then with secondary antibodies linked to $1.4 \mathrm{~nm}$ gold particles (Nanogold; Nanoprobes) for $2 \mathrm{~h}$. Immunogolds were intensified with a silver enhancement kit (R-GENT SE-EM, Aurion). Sections were treated with $1 \%$ osmium tetroxide for 15 min, stained in block with $2 \%$ uranyl acetate for 20 min, dehydrated, and embedded in Epon 812.

For postembedding immunogold electron microscopy, ultrathin sections on nickel grids were treated with successive solutions, as follows: saturated sodium ethoxide for $2 \mathrm{~s}, 50 \mathrm{~mm}$ glycine in incubation solution ( $0.03 \%$ Triton X-100 in Tris-buffered saline, $\mathrm{pH} 7.4$; TBST) for $10 \mathrm{~min}$, blocking solution containing $2 \%$ normal goat serum in TBST (GTBST) for $10 \mathrm{~min}$, rabbit $\mathrm{GABA}_{\mathrm{A}} \mathrm{R} \alpha 1$ or GluA2 antibody $(20 \mu \mathrm{g} / \mathrm{ml}$ for each) diluted in GTBST overnight, colloidal gold-conjugated $(10 \mathrm{~nm})$ antirabbit secondary antibody ( $1: 100$, British BioCell International) in GTBST for $2 \mathrm{~h}, 2 \%$ normal rabbit serum in TBST for $30 \mathrm{~min}$, guinea pig VGluT3 antibody in GTBST for $6 \mathrm{~h}$, and colloidal gold-conjugated (15 $\mathrm{nm})$ anti-guinea pig secondary antibody (1:100, British BioCell International) in GTBST for $2 \mathrm{~h}$. Sections were extensively washed with distilled water and stained with 5\% uranyl acetate $/ 40 \%$ ethanol for $90 \mathrm{~s}$ and Reynold's lead citrate solution for $90 \mathrm{~s}$. Photographs were taken with an H-7100 (Hitachi) or JEM1400 (JOEL) electron microscopes. For quantitative analysis, postsynaptic membrane-associated immunogold particles, defined as $<30 \mathrm{~nm}$ apart from the cell membrane, were counted on electron micrographs and analyzed using an ImageJ software.

\section{Results}

\section{VGluT3 ${ }^{+} / \mathrm{CCK}^{+}$interneurons highly express $\mathrm{CB}_{1}$ mRNA}

To grasp the pattern of overall expression, chromogenic in situ hybridization for $\mathrm{CB}_{1}$, VGluT3, and GAD67 mRNAs used coronal forebrain sections through the amygdala. Two distinct patterns of cellular expression were noted for $\mathrm{CB}_{1}$ mRNA in the forebrain (Fig. 1 $A, B$ ). Weak diffuse labeling and intense dispersed labeling coexisted in the cerebral cortex, hippocampus, and BA, whereas diffuse labeling was predominant in the striatum, central nucleus of the amygdala (CeA), and ventromedial hypothalamic nucleus. VGluT3 mRNA was expressed in the minority of cells dispersed in the cerebral cortex, hippocampus, striatum, and BA, whereas no such cells were found in the lateral nucleus of the amygdala (LA) and CeA (Fig. 1C,D). GAD67 mRNA was expressed in relatively few cells in the cerebral cortex, hippocampus, BA, and LA, whereas it was expressed in the majority of cells composing the CeA, striatum, reticular thalamic nucleus, zona incerta, and arcuate hypothalamic nucleus (Fig. $1 E, F)$. All these expression patterns are consistent with previous reports (Matsuda et al., 1993; Gras et al., 2002; Schäfer et al., 2002; Yoshida et al., 2011). No significant labeling was observed with use of sense riboprobes (data not shown). These data support the specificity of probes for in situ hybridization.

In the $\mathrm{BA}$, cells intensely expressing $\mathrm{CB}_{1}$ mRNA are known to be CCK-positive GABAergic interneurons (Marsicano and Lutz, 1999; Katona et al., 2001; McDonald and Mascagni, 2001). We characterized the neurochemical properties of VGluT3 mRNAexpressing cells by double-labeling FISH. All cells expressing VGluT3 mRNA expressed mRNAs for GAD67 ( $n=57$ cells), $\mathrm{CB}_{1}$ $(n=42)$, and preproCCK $(n=52)$ (Fig. $1 G-I$, arrowheads). In terms of expression patterns for $\mathrm{CB}_{1}$ and preproCCK mRNAs, cells in the BA were readily classified into strong and weak cells. All neurons expressing VGluT3 mRNA were $\mathrm{CB}_{1}$-strong and preproCCK-strong cells (Fig. $1 H$, arrowheads). There were also $\mathrm{CB}_{1}$-strong cells that had no detectable signals for VGluT3
mRNA (Fig. $1 H$, arrows). We found that VGluT3 mRNA was expressed in $27.6 \%$ of $\mathrm{CB}_{1}$-strong cells $(n=152)$. Conversely, most of the $\mathrm{CB}_{1}$-weak cells were pyramidal cells expressing VGluT1 mRNA, with the rest being GABAergic interneurons expressing GAD67 mRNA (data not shown). Therefore, all neurons expressing VGluT3 mRNA are $\mathrm{CB}_{1}$-strong/preproCCK-strong GABAergic interneurons, and they constitute one-fourth of $\mathrm{CB}_{1^{-}}$ strong cell populations in the BA.

\section{$\mathrm{VIP}^{+} / \mathrm{CCK}^{+}$interneurons weakly express $\mathrm{CB}_{1}$ mRNA}

In the hippocampus and cerebral cortex, VIP is also expressed in CCK-positive basket cells, but they constitute cell populations that are distinct from VGluT3-expressing ones (Somogyi et al., 2004). In the BA, interneurons expressing preproVIP mRNA were very low or negative for VGluT3 mRNA and vice versa (Fig. $1 J)$. All neurons expressing preproVIP mRNA were labeled for $\mathrm{CB}_{1}$ mRNA $(n=106)$, but the majority $(89.6 \%)$ were classified as $\mathrm{CB}_{1}$-weak cells. Thus, compared with VGluT3-expressing CCKpositive interneurons, VIP-expressing CCK-positive interneurons form distinct populations and express $\mathrm{CB}_{1}$ at much lower transcription levels in the BA.

\section{DGL $\alpha$ clusters beneath VGluT3 ${ }^{+} / \mathrm{CB}_{1}{ }^{+}$basket cell terminals}

Next, we pursued, by multiple-labeling immunofluorescence, the distribution of terminals derived from $\mathrm{CB}_{1} /$ VGluT3-expressing GABAergic interneurons in the BA. Almost all terminals with intense $\mathrm{CB}_{1}$ immunoreactivity overlapped with VIAAT, a marker of GABAergic and glycinergic inhibitory terminals. These $\mathrm{CB}_{1}{ }^{+} / \mathrm{VIAAT}^{+}$terminals were either VGluT3-positive (Fig. 2 A, arrowheads) or VGluT3-negative (arrows); both types formed perisomatic baskets around CaMKII $\alpha$-labeled pyramidal cell somata and were also distributed in the neuropil (Fig. 2A). Of these, VGluT3-positive $\mathrm{CB}_{1}{ }^{+}$/VIAAT ${ }^{+}$terminals constituted $56.6 \%$ and $31.5 \%$ of the total $\mathrm{CB}_{1}{ }^{+} / \mathrm{VIAAT}^{+}$terminals on the soma $(n=687)$ or in the neuropil $(n=54)$, respectively (Fig. $2 B)$, showing a statistically significant difference $\left(p=0.0005, \chi^{2}\right.$ test). Thus, VGluT3-positive $\mathrm{CB}_{1}{ }^{+} / \mathrm{VIAAT}^{+}$terminals preferentially target pyramidal cell somata in the BA. In the LA (Fig. 2C) or CeA (Fig. 2D), however, VGluT3 was mostly distributed in the neuropil, and rarely overlapped with VIAAT, suggestive of VGluT3 expression in nonGABAergic terminals.

Our previous study has shown that DGL $\alpha$, the major synthetic enzyme of 2-AG, is clustered on pyramidal cell somata and selectively apposed $\mathrm{CB}_{1}$-expressing CCK-positive basket cell terminals in the BA (Yoshida et al., 2011). To compare the extent of apposition of VGluT3-positive or VGluT3-negative basket cell terminals to DGL $\alpha$ clusters, we used quadruple immunofluorescence for these molecules (Fig. 2E). We found that $51.4 \%$ of pyramidal cells were associated with perisomatic DGL $\alpha$ clusters (Fig. 2E), whereas others were not, even if they were surrounded by $\mathrm{CB}_{1}{ }^{+} / \mathrm{VIAAT}^{+}$terminals (data not shown, $n=170$ ). In 97 pyramidal cell somata carrying DGL $\alpha$ clusters, $81.7 \%$ of VGluT3-positive $\mathrm{CB}_{1}{ }^{+}$/VIAAT ${ }^{+}$terminals were apposed to DGL $\alpha$ clusters (Fig. $2 E$, arrowheads, $n=246$ ), whereas only $28.8 \%$ of VGluT3-negative $\mathrm{CB}_{1}{ }^{+} / \mathrm{VIAAT}^{+}$terminals were opposite to DGL $\alpha$ clusters (Fig. $2 E$, arrows, $n=215$ ). When similar quadruple immunofluorescence analysis was applied to VIPpositive terminals, they were encountered much less frequently on pyramidal cell somata (Fig. $2 F$ ). Perisomatic VIP-positive terminals were colabeled for VIAAT and $\mathrm{CB}_{1}$, but DGL $\alpha$ clusters were not found beneath VIP-positive terminals $(n=15)$. These findings indicate that VGluT3, but not VIP, is preferentially expressed in DGL $\alpha$-apposing/CB $\mathrm{CB}_{1}$-expressing basket cell terminals. 

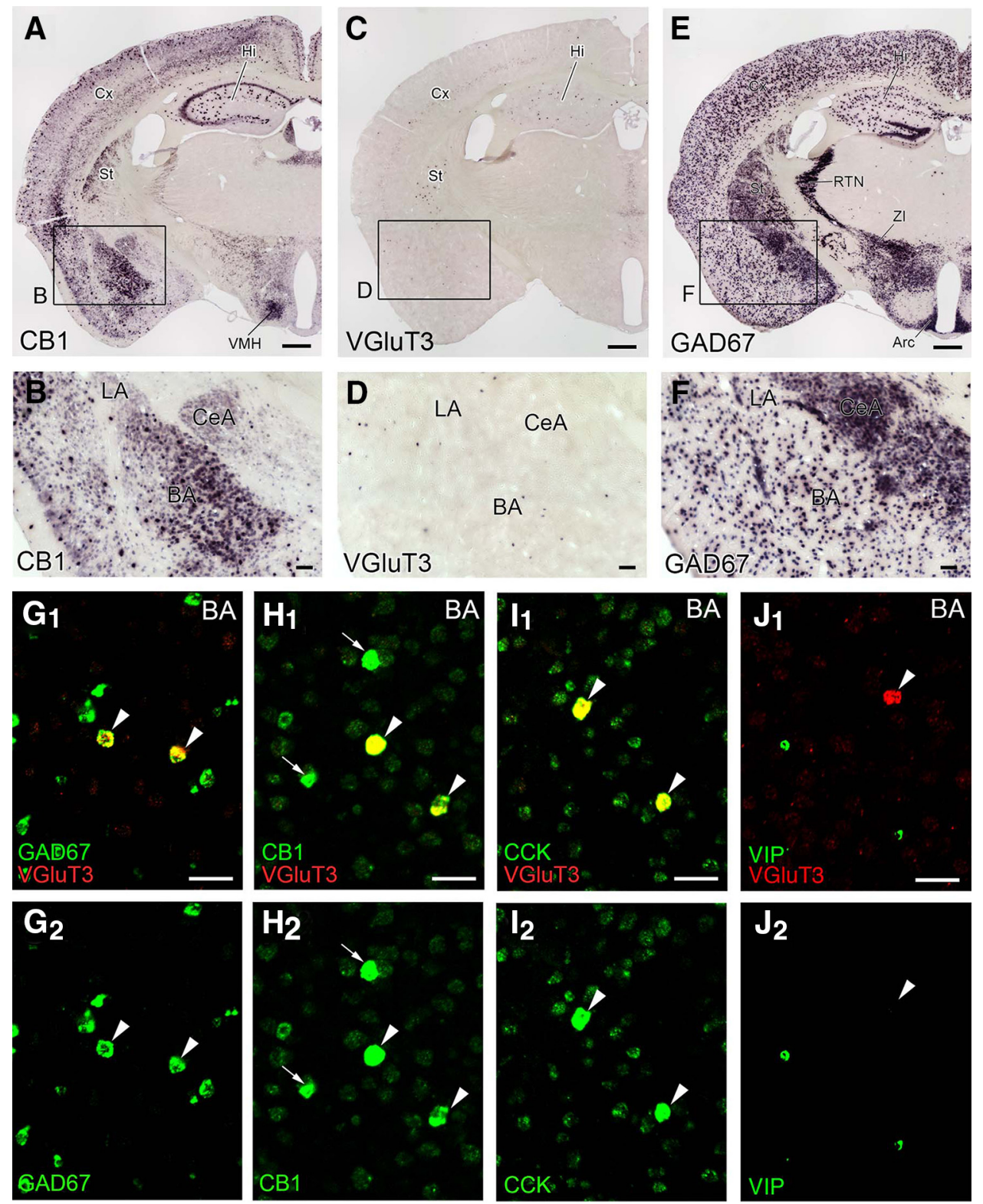

Figure 1. Selective expression of VGluT3 mRNA in GABAergic interneuron populations expressing $C_{1}$ and preproCCK mRNAs in the BA. $A-F$, Chromogenic in situ hybridization showing characteristic expression patterns of mRNAs for $\mathrm{CB}_{1}(\boldsymbol{A}, \boldsymbol{B}), \mathrm{VGluT3}(\boldsymbol{C}, \boldsymbol{D})$, and $\operatorname{GAD} 67(\boldsymbol{E}, \boldsymbol{F})$ in coronal forebrain sections through the amygdala in adult mice. $G-J$, Double-labeling FISH for VGluT3 mRNA (red) and neuronal markers (green) in the BA. Arrowheads indicate VGluT3 mRNA-expressing neurons that coexpress GAD67 (G), $B_{1}(\boldsymbol{H})$, or preproCCK $(\boldsymbol{I})$ mRNA at high levels but lack preproVIP mRNA expression $(\boldsymbol{J})$. $\boldsymbol{H}$, Arrows indicate $\mathrm{CB}_{1}$ mRNA-strong cells that lack VGluT3 mRNA expression. Arc, Arcuate hypothalamic nucleus; $\mathrm{C}_{\mathrm{X}}$, cerebral cortex; Hi, hippocampus; $\mathrm{RTN}$, reticular thalamic nucleus; St, striatum; VMH, ventromedial hypothalamic nucleus; Zl, zona incerta. Scale bars: $A, C, E, 500 \mu \mathrm{m} ; \boldsymbol{B}, \mathbf{D}, \boldsymbol{F}, 100 \mu \mathrm{m} ; \mathbf{G}-J, 50 \mu \mathrm{m}$.

\section{$\mathrm{VGluT3}^{+}$terminals selectively form invagination}

Because unique invagination is formed at $\mathrm{CB}_{1}$-positive basket cell synapses on pyramidal cell somata in the BA (Yoshida et al., 2011), we examined the morphology of synapses innervated by VGluT3-positive and VGluT3-negative terminals by preembedding immunoelectron microscopy (Fig. 3). Terminal profiles that formed symmetrical synaptic contacts on to pyramidal cell somata were sampled. We found that $91.2 \%$ of VGluT3positive terminals formed invagination into pyramidal cell somata (i.e., invaginating synapses, $n=34$ ), whereas none of the VGluT3-negative terminals formed invagination (i.e., flat synapses, $n=105$ ). These results indicate that VGluT3-expressing CCK-positive basket cell terminals selectively form invaginating synapses.

\section{$\mathrm{GABA}_{\mathrm{A}} \mathrm{Ra}$ 1 expression at invaginating synapses}

Symmetrical type of contacts at invaginating synapses in the BA (Yoshida et al., 2011) further suggests that the major transmitter mediating fast synaptic transmission is GABA. To confirm this from the molecular-anatomical point of view, we examined $\mathrm{GABA}_{\mathrm{A}} \mathrm{R} \alpha 1$ and glutamate receptor subunit GluA2 on the postsynaptic membrane of invaginating synapses by postembedding immunogold microscopy (Fig. 4). Invaginating synapses were sampled from profiles that formed structural invagination (Fig. $4 A, C$, filled arrows) and had immunogold labeling with more than two particles for VGluT3 in presynaptic terminals. We also sampled asymmetrical axo-dendritic synapses for comparison (images not shown). By counting the density of immunogold labeling per $1 \mu \mathrm{m}$ of the postsynaptic membrane for $\mathrm{GABA}_{\mathrm{A}} \mathrm{R} \alpha 1$ 

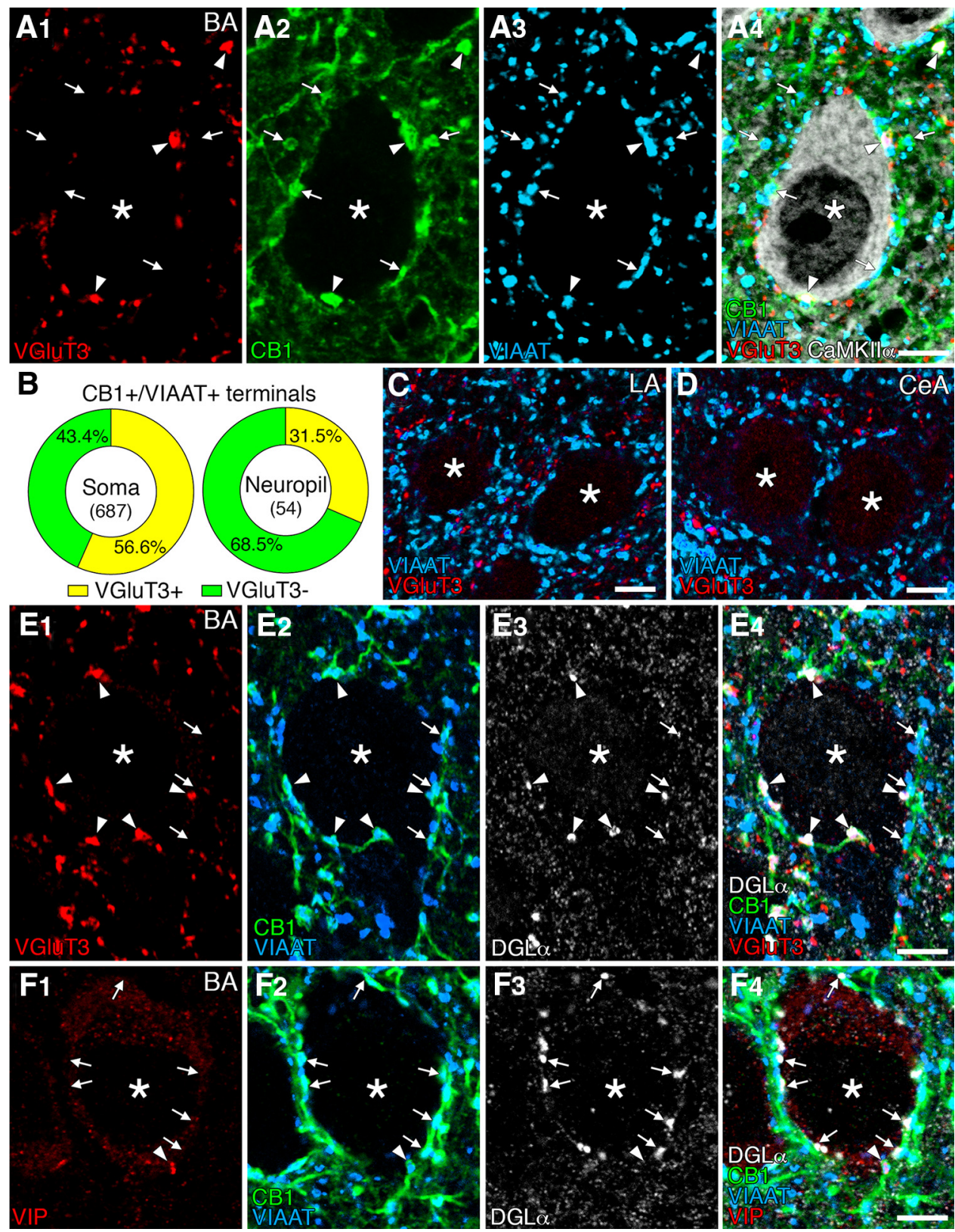

Figure 2. Immunofluorescence showing selective expression of $\mathrm{VGluT3}$ in $\mathrm{CB}_{1}{ }^{+} / \mathrm{VIAAT}^{+}$basket cell terminals and preferential DGL $\alpha$ clustering beneath VGluT3-positive $\mathrm{CB}_{1}{ }^{+} / \mathrm{VIAAT}^{+}$ terminals in the BA. A, Quadruple immunofluorescence for VGluT3 (red), CB (green), VIAAT (blue), and CaMKII $\alpha$ (white) in the BA. Arrowheads and arrows indicate VGluT3-positive or -negative $\mathrm{CB}_{1}{ }^{+} / \mathrm{VIAAT}^{+}$terminals, respectively, on CaMKIl $\alpha{ }^{+}$pyramidal cell somata (asterisks) and in the neuropil. $\boldsymbol{B}$, Pie graphs showing the ratio of VGluT3-positive (yellow) and VGluT3-negative (green) $\mathrm{CB}_{1}{ }^{+} / \mathrm{VIAAT}^{+}$terminals on the soma (left) and in the neuropil (right). Numerals in the center indicate the number of $\mathrm{CB}_{1}{ }^{+} / \mathrm{VIAAT}^{+}$terminals examined. $C, D$, Double immunofluorescence for VGluT3 (red) and VIAAT (blue) showing the lack of VGluT3-positive basket cell terminals on putative pyramidal cell somata in the $L A(B)$ and CeA ( $(C)$ amygdala. $\boldsymbol{E}$, Quadruple immunofluorescence for VGluT3 (red), $\mathrm{CB}_{1}$ (green), VIAAT (blue), and DGL $\alpha$ (white) in the BA. Arrowheads and arrows indicate VGluT3-positive or -negative $\mathrm{CB}_{1}{ }^{+} / \mathrm{VIAAT}^{+}$terminals, respectively, on putative pyramidal cell somata (asterisk). Note that VGluT3-positive terminals appose DGL $\alpha$ clusters, but VGluT3-negative ones do not, $\boldsymbol{F}$, Quadruple immunofluorescence for VIP (red), $\mathrm{B}_{1}$ (green), VIAAT (blue), and DGL $\alpha$ (white) in the BA. Arrowheads and arrows indicate VIP-positive or -negative $\mathrm{CB}_{1}{ }^{+} \mathrm{NIAAT}{ }^{+}$terminals, respectively, on putative pyramidal cell somata (asterisk). Note the lack of DGL $\alpha$ clusters beneath a VIP-positive terminal. Scale bars, $5 \mu \mathrm{m}$.

(Fig. 4B, open arrowheads) and GluA2 (Fig. 4D, open arrowheads) was $2.75 \pm 0.62($ mean \pm SE, $n=30)$ or $0.00 \pm 0.00(n=$ $12)$, respectively, at invaginating synapses, and $0.17 \pm 0.17(n=$ $25)$ or $1.67 \pm 0.61(n=24)$, respectively, at asymmetrical synapses. Thus, the postsynaptic receptor phenotype at invaginating synapses is GABAergic.

Extrasynaptic expression of $\mathrm{mGluR}_{5}$ in $\mathrm{BA}$ pyramidal cells To pursue a possible target of glutamate that may be coreleased from VGluT3-expressing basket cell terminals, we examined im- munohistochemical distribution of $\mathrm{mGluR}_{5}$ because it is one of the $\mathrm{G} \alpha_{\mathrm{q} / 11}$ protein-coupled glutamate receptors and expressed abundantly in pyramidal cells in the BA (Yoshida et al., 2011). Immunofluorescence showed a widespread and dense distribution of $\mathrm{mGluR}_{5}$ in the $\mathrm{BA}$, where $\mathrm{mGluR}_{5}$ was detected along the surface of MAP2-labeled somata and dendrites of putative pyramidal cells (Fig. $5 A$, arrows). mGluR $_{5}$ immunoreactivity showed no particular accumulation at, or gradient toward, DGL $\alpha$ clusters on pyramidal cell somata (Fig. 5A, arrowheads). By pre-embedding immunoelectron microscopy, metal 

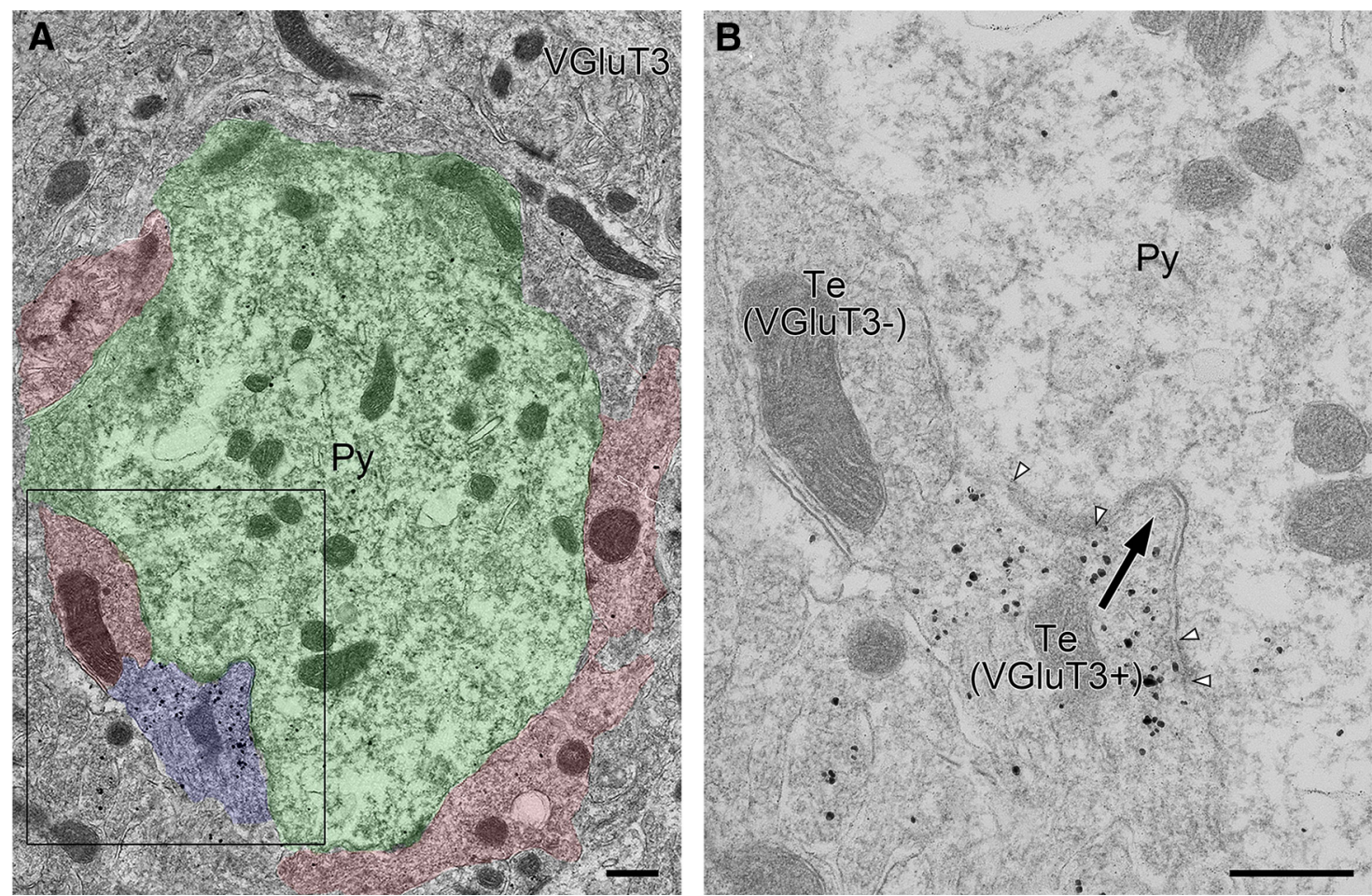

Figure 3. Pre-embedding immunogold electron microscopy showing selective formation of invagination by VGluT3-positive basket cell terminals in the BA. $A$, Low-magnification image pseudocolored for pyramidal cell soma (green), VGluT3-positive basket cell terminal (blue), and VGluT3-negative basket cell terminals (red). $\boldsymbol{A}$, Boxed region is enlarged in $\boldsymbol{B}$, where VGluT3-positive terminal forms invagination (arrow). Pairs of arrowheads indicate symmetrical synaptic contacts on the bank of invagination. Py, Pyramidal cell soma; Te, nerve terminal. Scale bars, $500 \mathrm{~nm}$.
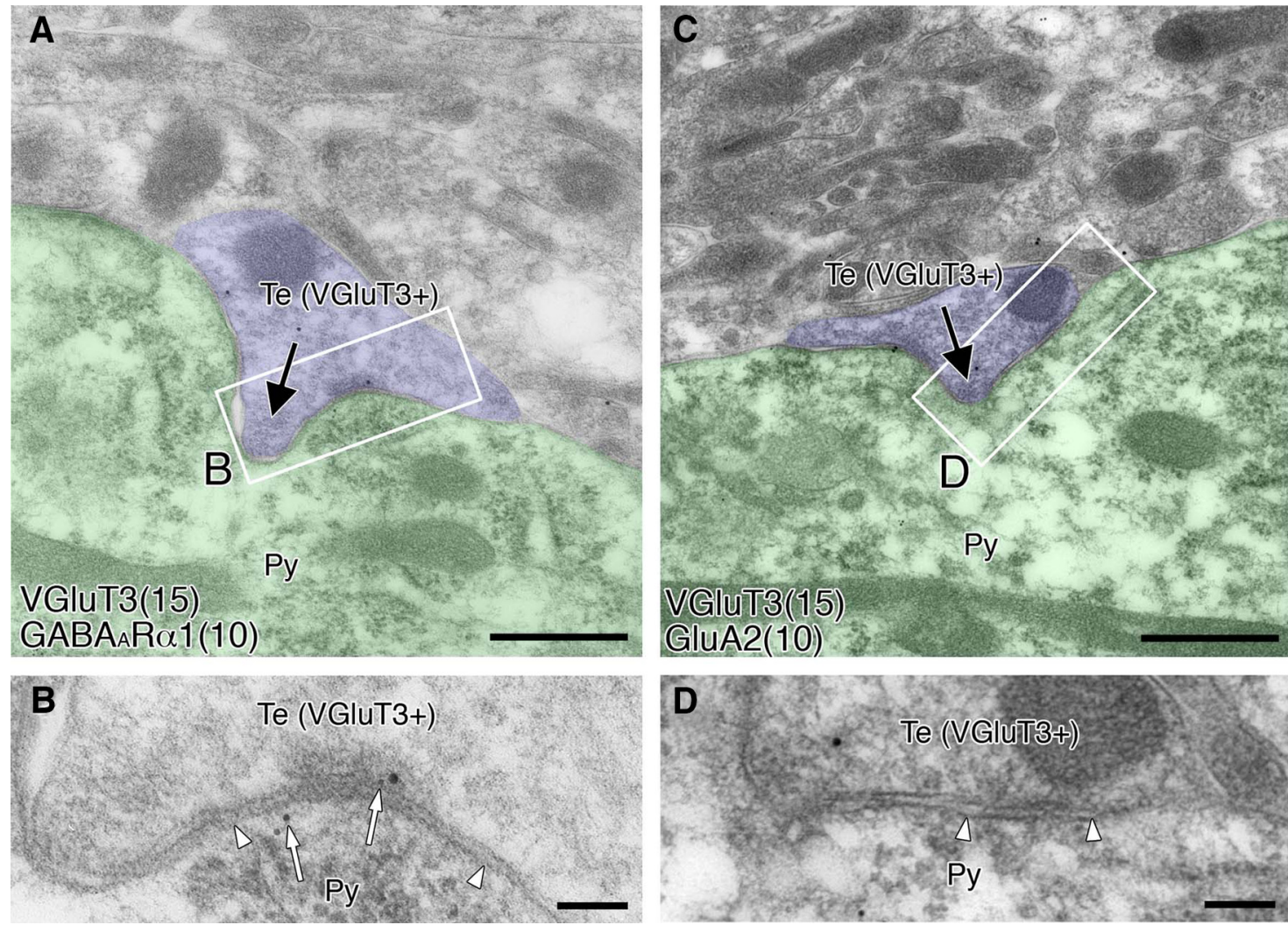

Figure 4. Postembedding immunogold electron microscopy showing GABAergic, but not glutamatergic, phenotype of the postsynaptic membrane at invaginating synapses in the BA. Doublelabeling was applied to VGluT3 ( $\phi=15 \mathrm{~nm}$ colloidal gold particles) and to $\mathrm{GABA}_{A} R \alpha 1(\boldsymbol{A}, \boldsymbol{B} ; \phi=10 \mathrm{~nm})$ or glutamate receptor subunit GluA2 $(C, D ; \phi=10 \mathrm{~nm})$ at invaginating synapses. $\boldsymbol{B}, 0$ pen arrows indicate immunogold labeling for $G_{A B A_{A}} R \alpha 1$ at invaginating synapse. $B, D$, Enlarged images of boxed regions in $A$ and $C$, respectively. Py, Pyramidal cell soma; Te, nerve terminal. Scale bars: $A, C, 500 \mathrm{~nm} ; B, D, 100 \mathrm{~nm}$. 

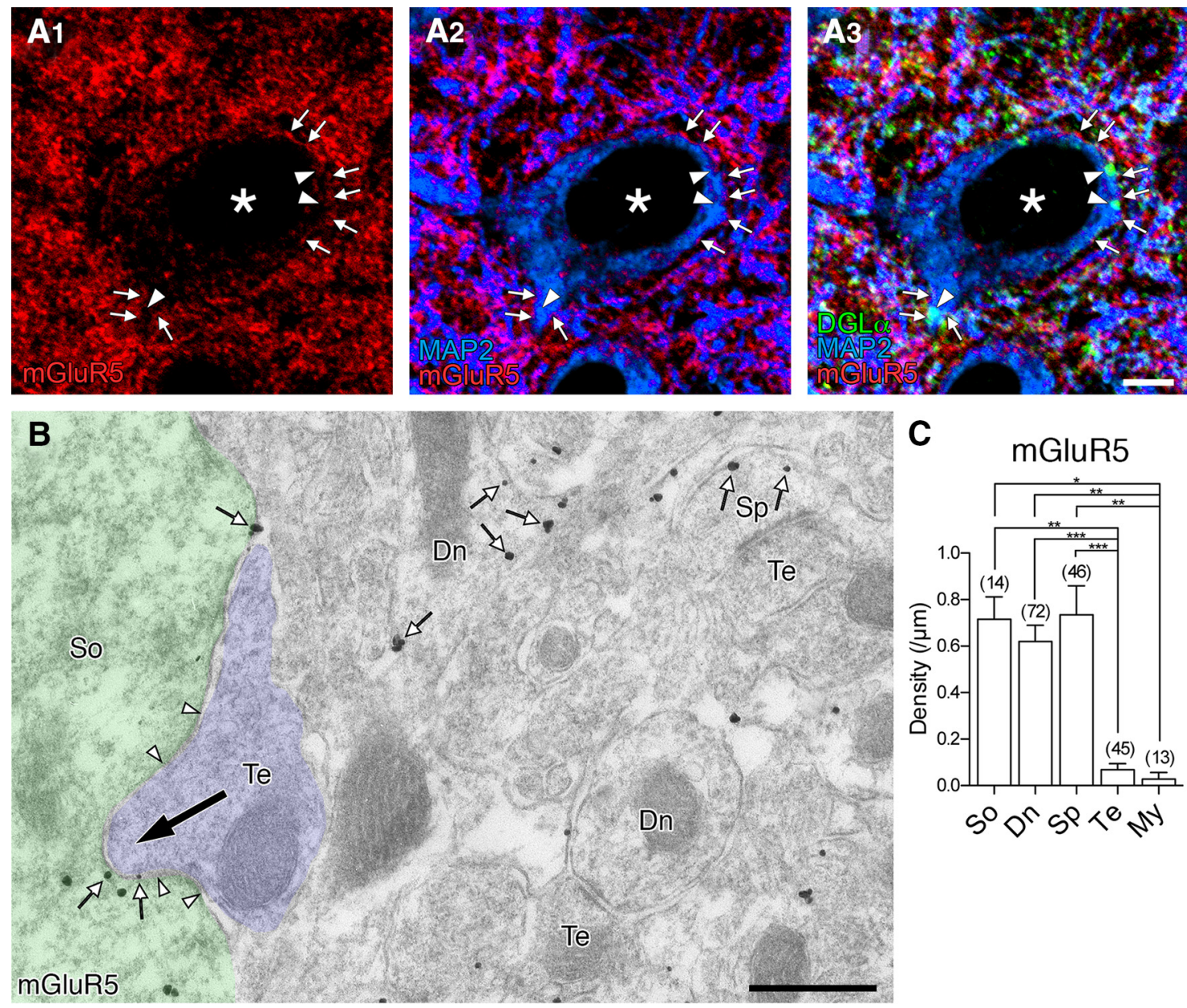

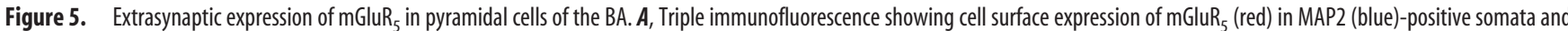
dendrites (arrows). Note no particular accumulation toward or around DGL $\alpha$ clusters (green, arrowheads). $\boldsymbol{B}$, Pre-embedding immunogold electron microscopy for $\mathrm{mGlu}_{5}$. Metal particles attaching to the cell membrane of the soma $\left(S_{0}\right)$, dendritic shafts $(\mathrm{Dn})$, and dendritic spines $(\mathrm{Sp})$ are indicated by small open arrows. Note no particular accumulation of mGluR $\mathrm{R}_{5}$ on the cell membrane facing an invaginating terminal (Te, large filled arrow). A pair of arrowheads indicate symmetrical synaptic contact. C, Bar graph showing the density of cell membrane-attached metal particles for mGlu $R_{5}$ in each neuronal compartment: So, Soma; Dn, dendritic shaft; Sp, dendritic spine; Te, nerve terminal; My, myelin sheath. Labeling on myelin sheath was calculated for negative control. Numerals on each bar indicate the number of measured profiles. ${ }^{* * *} p<0.001$ (one-way ANOVA with Tukey's post hoc test). ${ }^{* *} p<0.01$ (one-way ANOVA with Tukey's post hoc test). ${ }^{*} p<0.05$ (one-way ANOVA with Tukey's post hoc test). Scale bars: $A, 5 \mu \mathrm{m} ; \boldsymbol{B}, 500 \mathrm{~nm}$.

particles for $\mathrm{mGluR}_{5}$ were widely distributed on the extrasynaptic surface and intracellular sites of somata, dendritic shafts, and dendritic spines of putative pyramidal cells (Fig. $5 B$ ). The synaptic membrane was rarely labeled for $\mathrm{mGluR}_{5}$, except for the synaptic edge. The density of plasma membrane-attached metal particles was similarly high in these somatodendritic compartments, compared with nerve terminals and myelin sheath (Fig. $5 C)$. Therefore, $\mathrm{mGluR}_{5}$ is widespread on the extrasynaptic surface of somatodendritic elements in BA pyramidal cells.

High expression of $\mathrm{CCK}_{2} \mathrm{R}$ mRNA in BA pyramidal cells

The neurochemical phenotype also suggests that CCK is coreleased from terminals forming invaginating synapses. Because specific $\mathrm{CCK}_{2} \mathrm{R}$ antibodies applicable to immunohistochemistry were not available, we examined its expression by FISH. Antisense riboprobe for $\mathrm{CCK}_{2} \mathrm{R}$ mRNA labeled the BA intensely (Fig. $6 A, C)$. By double-labeling in situ hybridization, $\mathrm{CCK}_{2} \mathrm{R}$ mRNA was detected in both pyramidal cells expressing VGluT1 mRNA (Fig. 6B) and interneurons expressing GAD67 mRNA (Fig. 6D), with higher levels in the former.

\section{Differential distribution of invaginating synapses in cortical regions}

We examined whether perisomatic synapses with intensive molecular assembly of VGluT3, $\mathrm{CB}_{1}$, and DGL $\alpha$ were also present in cortical regions (Fig. 7). By quadruple immunofluorescence for VGluT3, CB1, VIAAT (or DGL $\alpha$ ), and CaMKII $\alpha$, VGluT3positive $\mathrm{CB}_{1}{ }^{+} / \mathrm{VIAAT}^{+}$terminals were attached to CaMKII $\alpha$ labeled pyramidal cell somata (Fig. $7 A$, arrowheads) and preferentially apposed DGL $\alpha$ clusters (Fig. $7 B$, arrowheads) in the primary motor cortex, as seen in the BA. In contrast, although they formed pericellular baskets around pyramidal cell somata, DGL $\alpha$ clusters were not formed beneath VGluT3-positive $\mathrm{CB}_{1}{ }^{+}$/ VIAAT $^{+}$terminals in the hippocampal CA1 (Fig. 7C, arrowheads). Instead, DGL $\alpha$ was expressed widely on the surface of CA1 pyramidal cell somata, regardless of pericellular baskets (Fig. 7C).

To quantify the differences, we measured the frequency of pyramidal cells that were attached by more than one VGluT3positive $\mathrm{CB}_{1}{ }^{+} / \mathrm{VIAAT}^{+}$terminal or had more than one DGL $\alpha$ cluster around CaMKII $\alpha$-labeled pyramidal cell somata in the 

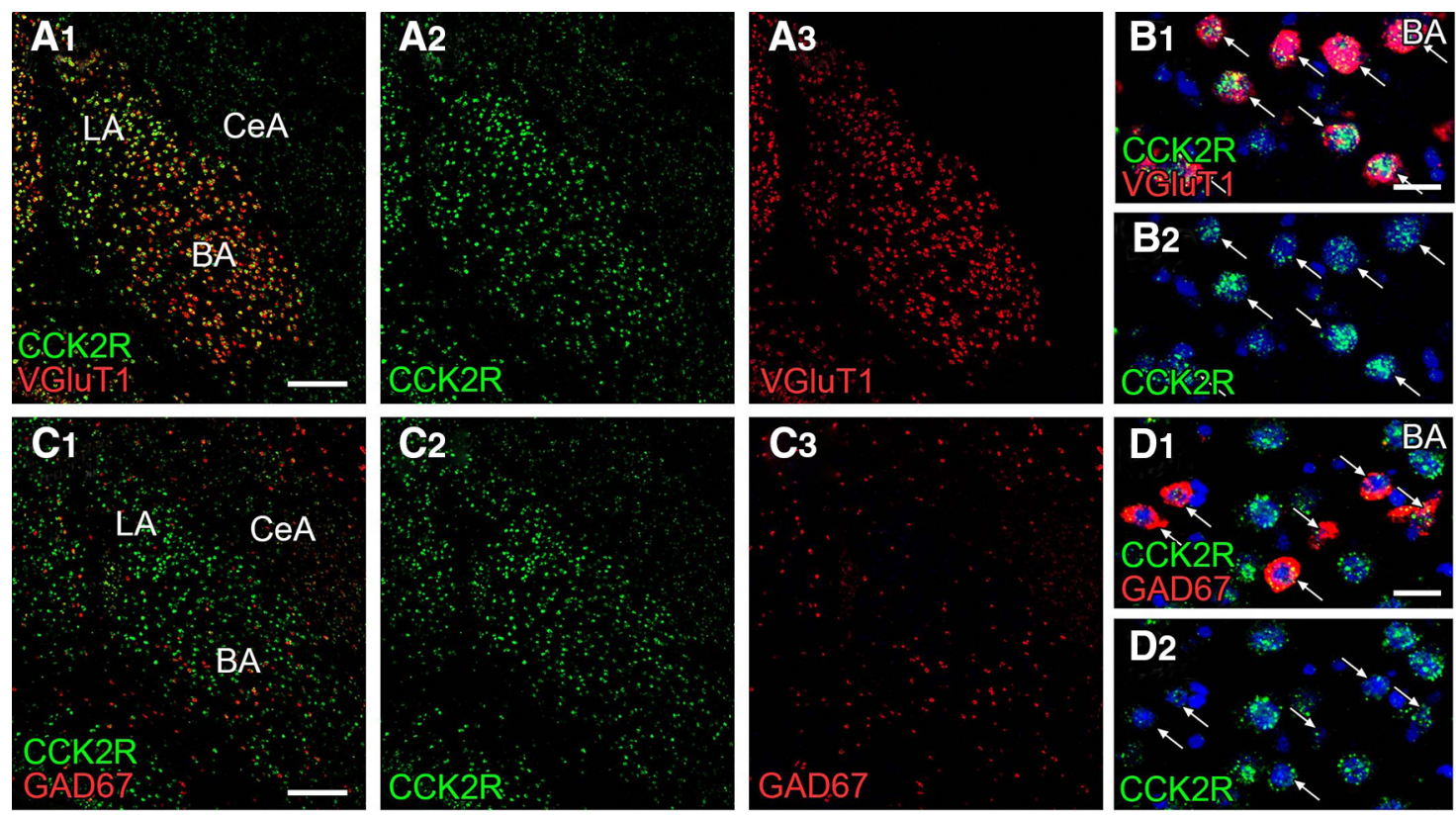

Figure 6. FISH showing abundant neuronal expression of $C_{C} \mathrm{CK}_{2} \mathrm{R} m \mathrm{mRA}$ in the BA and LA. There are higher levels of hybridizing signals for $\mathrm{CCK}_{2} \mathrm{R}$ mRNA (green) in VGluT1-expressing pyramidal cells (red, arrows; $\boldsymbol{A}, \boldsymbol{B})$ than in GAD67-expressing interneurons (red, arrows; $\boldsymbol{C}, \boldsymbol{D})$ in the BA. Scale bars: $\boldsymbol{A}, \boldsymbol{C}, 200 \mu \mathrm{m} ; \boldsymbol{B}, \boldsymbol{D}, 20 \mu \mathrm{m}$.

cortical regions and amygdala. Pyramidal cells attached by VGluT3-positive $\mathrm{CB}_{1}{ }^{+} / \mathrm{VIAAT}^{+}$terminals were more or less found in various cortical regions, of which the hippocampal CA1 was most abundant and the medial prefrontal cortex was least (Fig. 7D, red columns). In comparison, the frequency of pyramidal cells having DGL $\alpha$ clusters was highly viable among cortical regions (Fig. $7 D$, blue columns), showing no particular relationship to those attached by VGluT3-positive terminals. Reflecting this regional heterogeneity of perisomatic DGL $\alpha$ clusters, pyramidal cells with VGluT3-positive $\mathrm{CB}_{1}{ }^{+} / \mathrm{VIAAT}^{+}$terminals apposing DGL $\alpha$ clusters were frequent in the primary motor, secondary motor, entorhinal, and primary somatosensory cortices, as in the BA, whereas they were rare in the hippocampal CA1 and medial prefrontal cortex, as in the LA and CeA (Fig. $7 D$, green columns). Therefore, perisomatic synapses with the molecular assembly characteristic of invaginating synapses are also present in cortical regions, but the frequency of occurrence is considerably variable among cortical regions, as is the case for cortex-like amygdala (i.e., the BA vs the LA).

\section{Invaginating synapses in the entorhinal cortex}

Finally, we scrutinized perisomatic synapses in the entorhinal cortex (Fig. 8). Again here, VGluT3-positive $\mathrm{CB}_{1}{ }^{+} / \mathrm{VIAAT}^{+}$terminals were frequently encountered around CaMKII $\alpha$-labeled pyramidal cell somata (Fig. $8 A$, arrowheads), and these terminals often apposed DGL $\alpha$ clusters (Fig. 8B, arrowheads). VGluT3positive $\mathrm{CB}_{1}{ }^{+} / \mathrm{VIAAT}^{+}$terminals constituted $32.3 \%$ of the total $\mathrm{CB}_{1}{ }^{+} / \mathrm{VIAAT}^{+}$terminals on the soma (Fig. $8 C ; n=226$ ). Moreover, in 46 pyramidal cell somata carrying DGL $\alpha$ clusters, $75.0 \%$ of VGluT3-positive $\mathrm{CB}_{1}{ }^{+} / \mathrm{VIAAT}^{+}$terminals were apposed to DGL $\alpha$ clusters $(n=108)$, whereas only $28.8 \%$ of VGluT3negative $\mathrm{CB}_{1}{ }^{+} / \mathrm{VIAAT}^{+}$terminals were apposed to DGL $\alpha$ clusters $(n=111)$. We further confirmed selective formation of invaginating synapses by VGluT3-positive basket cell terminals (Fig. $8 D$ ) or at DGL $\alpha$-clustered sites (Fig. $8 E$ ) in the entorhinal cortex. Together, invaginating synapses, at which DGL $\alpha$ is selec- tively clustered beneath VGluT3/CB 1 -expressing basket cell terminals, are formed in particular cortical regions.

\section{Discussion}

GABAergic interneurons are classified on the basis of firing patterns, molecular expression profiles, and innervations of distinct subcellular domains of pyramidal cells. VGluT3-expressing CCK-positive basket cells are one of at least 21 interneuron classes in the hippocampus CA1 (Somogyi et al., 2004; Klausberger and Somogyi, 2008) and highly express $\mathrm{CB}_{1}$ in cortical regions and BLA (Katona et al., 1999, 2001; Marsicano and Lutz, 1999; Tsou et al., 1999; Boder et al., 2005). Specific spike timing of CCK-positive interneurons in hippocampal network oscillations and their sensitivity to eCBs have been thought to link to mnemonic processes (Robbe et al., 2006; Lasztóczi et al., 2011). Selective VGluT3 expression in $\mathrm{CB}_{1}$-expressing CCK-positive basket cells in the BA is thus consistent with the framework of cortical interneuron diversity. In the $\mathrm{BA}$, we found that $56.6 \%$ of $\mathrm{CB}_{1}$ expressing basket cell terminals around pyramidal cell somata were immunopositive for VGluT3, and that $81.7 \%$ of VGluT3positive $\mathrm{CB}_{1}$-expressing basket cell terminals apposed DGL $\alpha$ clusters in pyramidal cells carrying DGL $\alpha$ clusters. Electron microscopically, $91.2 \%$ of VGluT3-positive terminals formed invagination, but none of VGluT3-negative terminals did it. Therefore, an original important finding in the present study is that VGluT3-expressing CCK-positive basket cells selectively construct invaginating synapses, as schematically depicted in Figure 9.

\section{Tripartite transmitter phenotype at invaginating synapses}

Whereas classical glutamatergic neurons express VGluT1 and VGluT2, VGluT3 is expressed in subsets of GABAergic, serotonergic, and cholinergic neurons (Fremeau et al., 2002; Gras et al., 2002; Herzog et al., 2004; Somogyi et al., 2004). It has been shown that glutamate is indeed coreleased from terminals of VGluT3expressing neurons (Varga et al., 2009; Noh et al., 2010; Higley et 

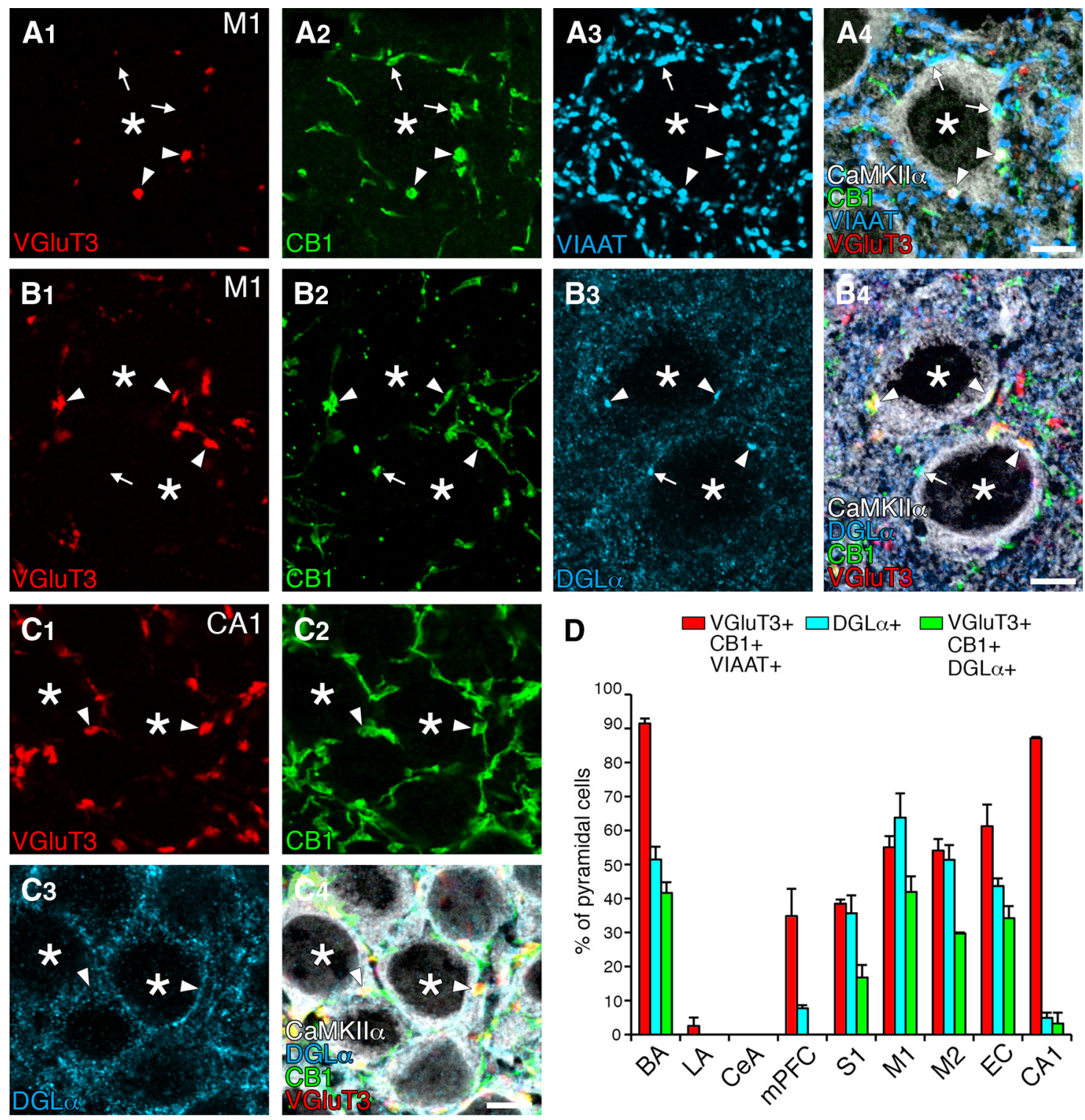

Figure 7. Cortical region-dependent DGL $\alpha$ clustering beneath VGluT3-positive CB1 ${ }^{+} / \mathrm{VIAAT}{ }^{+}$terminals. A, Quadruple immunofluorescence for VGluT3 (red), CB (green), VIAAT (blue), and CaMKIl $\alpha$ (white) in the primary motor cortex. Arrowheads and arrows indicate VGluT3-positive or-negative $\mathrm{CB}_{1}{ }^{+} / \mathrm{VIAAT}^{+}$terminals, respectively, on CaMKIl $\alpha^{+}$pyramidal cell somata (asterisks). $\boldsymbol{B}, \boldsymbol{C}$, Quadruple immunofluorescence for VGluT3 (red), $\mathrm{B}_{1}$ (green), DGL $\alpha$ (blue), and CaMKIl $\alpha$ (white) in the primary motor cortex (B) and hippocampal CA1 region (C). Arrowheads and arrows indicate VGluT3-positive or -negative $\mathrm{CB}_{1}{ }^{+}$terminals, respectively, on CaMKII $\alpha{ }^{+}$pyramidal cell somata (asterisk). VGluT3-positive terminals appose DGL $\alpha$ clusters in the primary motor cortex, but not in the hippocampal CA1.D, Bar graphs showing differential DGL $\alpha$ clustering beneath VGluT3-positive $C B 1^{+} / \mathrm{NIAAT}^{+}$terminals among cortical regions. The ordinate indicates the percentage of pyramidal cells whose cell bodies are associated with more than one VGluT3-positive $\mathrm{CB}^{+}{ }^{+}$NIAAT ${ }^{+}$terminal (red), more than one DGL $\alpha$ cluster (blue), or more than one DGL $\alpha$ clusters in apposition to VGluT3-positive $\mathrm{CB}_{1}{ }^{+}$terminals (green). We analyzed CaMKIll $\alpha^{+}$pyramidal cells in the basal (BA; 165 pyramidal cells for VGluT3 expression, 170 for DGL $\alpha$ clustering) and lateral (LA; $32,58)$ nuclei of the amygdala, and the medial prefrontal cortex (mPFC; 119, 117), primary somatosensory cortex (S1; 114, 134), primary motor cortex (M1; 176, 169), secondary motor cortex (M2; $159,104)$, entorhinal cortex (EC; 133, 209), and hippocampal CA1 (CA1; 70, 61). In the CeA, we analyzed 66 cells for VGluT3 expression and 53 cells for DGL $\alpha$ clustering. In laminated cortices, we analyzed the layer II/III. Scale bars, $5 \mu \mathrm{m}$.

al., 2011; Nelson et al., 2014). Thus, our finding further highlights that tripartite transmitter phenotype of GABA/glutamate/CCK is the common neurochemical feature of invaginating synapses.

Corresponding to this notion, we detected $\mathrm{GABA}_{\mathrm{A}} \mathrm{R} \alpha 1$, $\mathrm{mGluR}_{5}$, and $\mathrm{CCK}_{2} \mathrm{R}$ expression in BA pyramidal cells. Of these, $\mathrm{GABA}_{\mathrm{A}} \mathrm{R} \alpha 1$ accumulated on the postsynaptic membrane at invaginating synapses, whereas mGluR $_{5}$ was widely distributed on the extrasynaptic somatodendritic surface. Predominant extrasynaptic expression of $\mathrm{mGluR}_{5}$ is common to hippocampal pyramidal cells and striatal medium spiny neurons (Baude et al., 1993; Lujan et al., 1996; Uchigashima et al., 2007). The distinct subcellular distribution of distinct receptor classes suggests that
GABA is involved in fast inhibitory synaptic transmission via the mode of wired transmission, whereas glutamate, in addition to its well-known wired transmission for fast excitatory synaptic transmission at excitatory synapses, modulates neuronal and synaptic functions via the mode of volume transmission. The former notion is supported by the findings that invaginating synapses are symmetrical type of contacts typical to inhibitory synapses (Yoshida et al., 2011), and that inhibitory synapses on BLA pyramidal cells undergo $\mathrm{CB}_{1}$-mediated short-term depolarization-induced suppression of inhibition (DSI) and long-term depression (Katona et al., 2001; Marsicano et al., 2002; Azad et al., 2004; Zhu and Lovinger, 2005; Yoshida et al., 2011). The latter notion is com- 

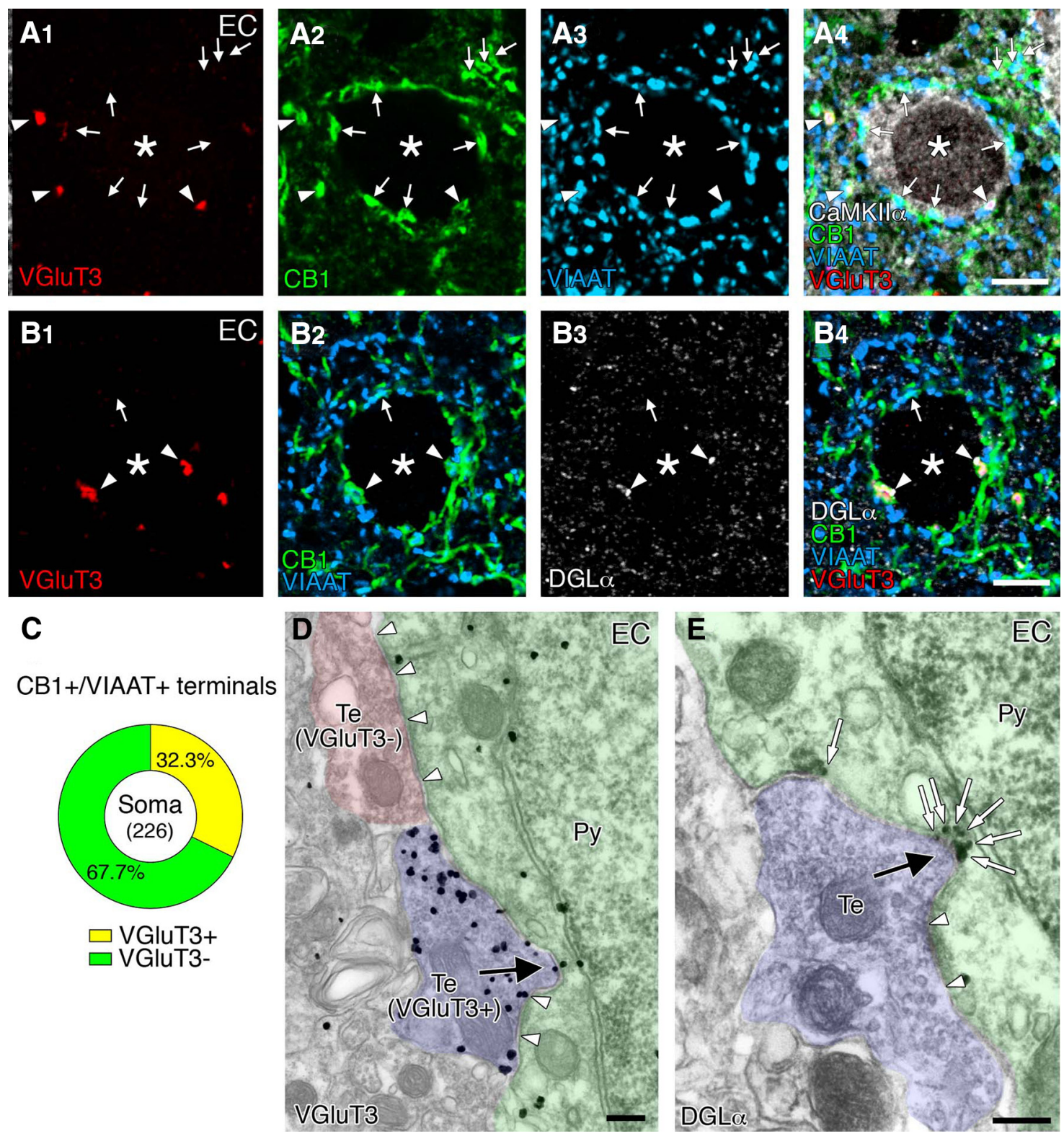

Figure 8. Frequent formation of invaginating synapses with intensive assembly of VGluT3, $\mathrm{CB}_{1}$, and DGL $\alpha$ in the entorhinal cortex. $A_{1}$, Quadruple immunofluorescence for VGluT3 (red), $\mathrm{B}_{1}$ (green), VIAAT (blue), and CaMKII $\alpha$ (white). Arrowheads and arrows indicate VGluT3-positive or -negative $\mathrm{CB}_{1}{ }^{+} / \mathrm{NIAAT}^{+}$terminals, respectively, on CaMKII $\alpha^{+}$pyramidal cell somata (asterisks). $B$, Quadruple immunofluorescence for VGluT3 (red), $\mathrm{CB}_{1}$ (green), DGL $\alpha$ (blue), and CaMKIl $\alpha$ (white). Arrowheads and arrows indicate VGluT3-positive or -negative $\mathrm{CB}_{1}{ }^{+}$terminals, respectively, on putative pyramidal cell somata (asterisk). VGluT3-positive terminals appose to DGL $\alpha$ clusters. C, Pie graph showing the ratio of VGluT3-positive (yellow) and VGluT3-negative (green) $\mathrm{CB}_{1}{ }^{+} /$ $\mathrm{VIAAT}^{+}$terminals on pyramidal cell somata. Numerals in the center indicate the number of $\mathrm{CB}_{1}{ }^{+} / \mathrm{VIAAT}{ }^{+}$terminals examined. $\boldsymbol{D}, \boldsymbol{E}$, Pre-embedding immunogold electron microscopy for VGluT3 (D) and $\operatorname{DGL} \alpha(\boldsymbol{E})$ in the entorhinal cortex. Note the formation of structural invagination by VGluT3-positive nerve terminals $(\boldsymbol{D}$, arrow). Also note $D G L \alpha$ clustering at the concavity of somatic membranes apposing invaginating terminals ( $\boldsymbol{E}$, open arrows). Arrowheads indicate symmetric synaptic contacts on pyramidal cell somata. Scale bars: $\boldsymbol{A}, \boldsymbol{B}, 5 \mu \mathrm{m} ; \boldsymbol{D}, \boldsymbol{E}, 200 \mathrm{~nm}$.

patible with the fact that $\mathrm{mGluR}_{5}$ blockade shortens the duration of DSI in the BLA (Zhu and Lovinger, 2005) and abolishes CB1mediated short-tem synaptic depression in the hippocampus (Sheinin et al., 2008).

Such modulatory roles by glutamate may hold true for CCK. Both CCK and $\mathrm{CCK}_{2} \mathrm{R}$ are densely expressed in the BLA (Larsson and Rehfeld, 1979; Vanderhaeghen et al., 1985; Honda et al., 1993; Mascagni and McDonald, 2003), and rich $\mathrm{CCK}_{2} \mathrm{R}$ mRNA expression in BA pyramidal cells was shown in the present study. Although subcellular localization of $\mathrm{CCK}_{2} \mathrm{R}$ remains unclear, direct $\mathrm{CCK}_{2} \mathrm{R}$-mediated excitation of pyramidal cells in the BLA suggests its expression, at least, in somatodendritic neuronal elements (Meis et al., 2007; Chung and Moore, 2009). Together, the tripartite transmitter-receptor system appears to reflect cooperative control of synaptic transmission and modulation by invaginating synapses, presumably to propel some specific synaptic mechanisms.

Postulated synaptic mechanisms by invaginating synapses What kinds of synaptic mechanisms can be predicted from the unique molecular-anatomical entity of invaginating synapses? Production of 2-AG in postsynaptic neurons is driven by three mechanisms: strong depolarization-induced $\left[\mathrm{Ca}^{2+}\right]_{i}$ elevation, strong $\mathrm{G} \alpha_{\mathrm{q} / 11}$-coupled receptor activation at basal $\left[\mathrm{Ca}^{2+}\right]_{\mathrm{i}}$ level, and combined $\left[\mathrm{Ca}^{2+}\right]_{\mathrm{i}}$ elevation and $\mathrm{G} \alpha_{\mathrm{q} / 11}$-coupled receptor activation (Hashimotodani et al., 2007c; Kano et al., 2009). The 


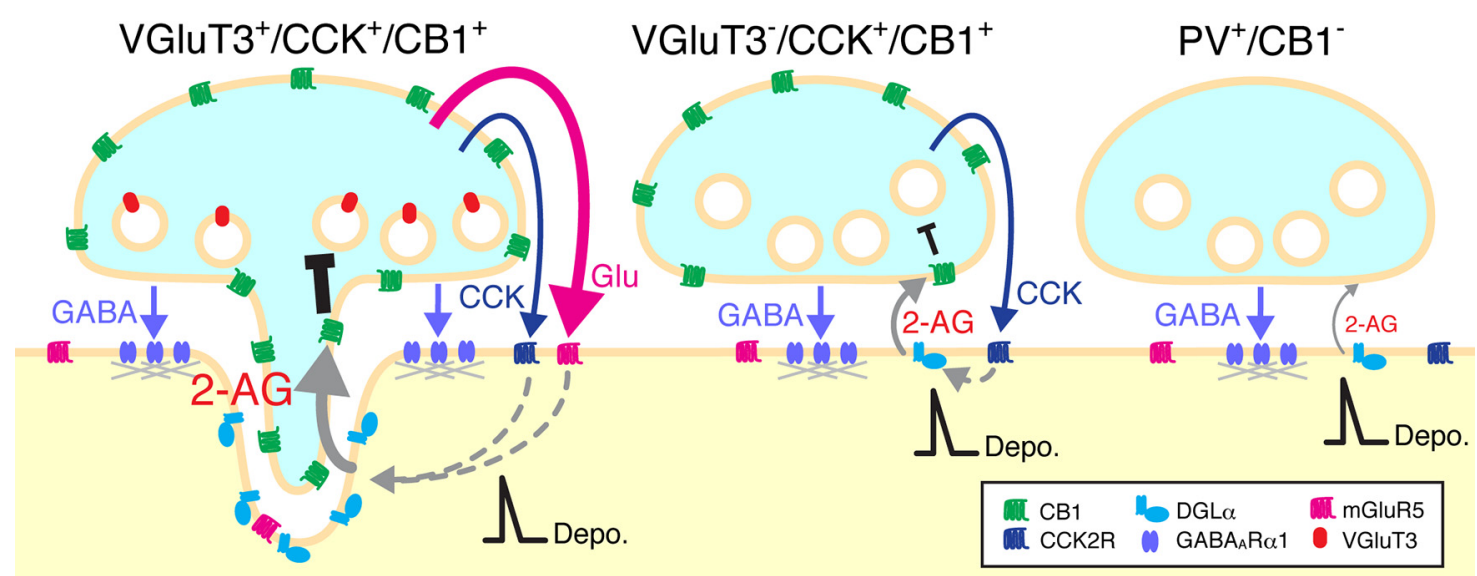

Figure 9. Schematic illustrations summarizing distinct molecular-anatomical architectures for 2-AG-mediated retrograde signaling at three types of basket cell-pyramidal cell synapses in cortical and cortex-like amygdaloid regions. Left, VGluT3-positive (CK basket cell synapse (invaginating synapse). Middle, VGluT3-negative CCK basket cell synapse (flat synapse). Right, Parvalbumin (PV)-positive basket cell synapse (flat synapse). Prevailing scheme has dichotomized basket cell synapses into (CK basket cell synapses with high (B, expression and PV basket cell synapses lacking $\mathrm{CB}_{1}$ expression (Freund, 2003; Kano et al., 2009). The present study has disclosed that VGluT3-positive CCK basket cells selectively construct invaginating synapses on pyramidal cells. At invaginating synapses, basket cell terminals may corelease GABA, glutamate, and CCK (tripartite transmitters), of which GABA is involved in fast inhibitory synaptic transmission, whereas glutamate and CCK modulate neuronal and synaptic functions through activation of $\mathrm{mGluR}_{5}$ and $\mathrm{CCK}_{2} \mathrm{R}$. Activation of these $\mathrm{G} \alpha_{\mathrm{q} / 11}$ protein-coupled receptors, together with depolarization-induced [ $\left.\mathrm{Ca}^{2+}\right]_{\mathrm{i}}$ elevation, should facilitate 2-AG-mediated retrograde suppression of transmitter release. Furthermore, extreme proximity of DGL $\alpha$ with $\mathrm{CB}_{1}$ at invaginating synapses makes them prone to induce 2-AGmediated tonic inhibition, compared with VGluT3-negative CCK basket cell synapses.

first prediction is that, on pyramidal cells, glutamate and CCK, which are released at invaginating synapses and also at excitatory synapses, activate $\mathrm{G} \alpha_{\mathrm{q} / 11}$ protein-coupled $\mathrm{mGluR}_{5}$ and $\mathrm{CCK}_{2} \mathrm{R}$, respectively. If the receptor activation is strong enough to produce 2-AG by itself, $\mathrm{CB}_{1}$-mediated retrograde suppression of GABA release may be induced at invaginating synapses. Even if the $\mathrm{mGluR}_{5}$ and $\mathrm{CCK}_{2} \mathrm{R}$ activation is subthreshold, 2-AG production can be facilitated when combined with depolarizationinduced $\left[\mathrm{Ca}^{2+}\right]_{\mathrm{i}}$ elevation upon elevated network activities and oscillations. Hence, this facilitative mechanism, together with high $\mathrm{CB}_{1}$ expression, may underlie lower induction thresholds and larger amplitudes of retrograde suppression of GABA release at invaginating synapses, compared with other inhibitory and excitatory synapses (Yoshida et al., 2011).

Structural distinction of invaginating synapses is the expansion of nonsynaptic contact areas by protrusion of presynaptic terminals and the corresponding concavity of somatic membranes. GABAergic synapses, on the other hand, are formed on the bank of invaginations (i.e., in the periphery of invaginating synapses) (Fig. 9, left). Notably, DGL $\alpha$ exclusively accumulated in the nonsynaptic contact areas of the postsynaptic concavity and faces $\mathrm{CB}_{1}$ at the presynaptic protrusions with a narrow gap of the intercellular space (Yoshida et al., 2011). Because of this extreme proximity, $\mathrm{CB}_{1}$ at invaginating synapses, compared with that at conventional synapses, is expected to bind 2-AG in a more readily saturable manner, once it is produced, even in small amounts. Therefore, the second prediction is that invaginating synapses regulate pyramidal cell activities by not only phasic but also tonic inhibition of GABA release through intensive activation of $\mathrm{CB}_{1}$. In the hippocampus, while large postsynaptic responses are elicited in pyramidal cells by activating CCK-positive basket cells, eCBs tonically inhibit GABA-mediated responses at some CCK-positive interneuron to pyramidal cell synapses in target cell-dependent and neuronal domain-specific manners (Losonczy et al., 2004; Ali and Todorova, 2010; Lee et al., 2010). Although DGL $\alpha$ was not clustered beneath basket cell terminals, its wide somatic expression in hippocampal pyramidal cells (Fig. 7C) may mediate this topic inhibition. Together, it can be as- sumed that invaginating synapses are evolved to be prone to undergo 2-AG-mediated tonic inhibition of transmitter release. Induction and disruption of tonic inhibition under certain physiological and pathophysiological conditions that affect basket cell activities, surface expression of $\mathrm{CB}_{1}$, and ambient 2-AG concentrations could potently alter the excitability and firing patterns of pyramidal cells.

CCK is a potent anxiogenic neuropeptide that promotes anxiety-like behavior and cued fear expression in rodents and elicits panic attacks in humans (Belcheva et al., 1994; Kennedy et al., 1999; Chen et al., 2006). Intriguingly, signaling systems through $\mathrm{CCK}_{2} \mathrm{R}$ and $\mathrm{CB}_{1}$ counteract fear memory extinction (Marsicano et al., 2002; Chhatwal et al., 2009). Based on the observation that impaired fear memory extinction by pharmacological $\mathrm{CB}_{1}$ blockade is reversed by intra-BLA infusion of $\mathrm{CCK}_{2} \mathrm{R}$ antagonist, Chhatwal et al. (2009) have proposed that the impaired extinction learning by $\mathrm{CB}_{1}$ antagonism is mediated by an inability of eCBs to reduce CCK release. According to this hypothesis, the third prediction is that invaginating synapses are a neuronal device to effectively mute CCK signaling upon activation of $\mathrm{CB}_{1}$. Because activities of CCK-positive basket cells are highly sensitive to emotional, motivational, and physiological states of the animal (Freund, 2003), functional interplay of eCB and CCK signaling likely provides invaginating synapses with retrogradely modulatable mechanisms for CCK release, which may further enable fine-tuning of pyramidal cell oscillations and coordination in activity- and state-dependent manners. These predictions need to be tested in future experiments.

\section{Anatomical invagination and DGL $\alpha$ clustering}

In various cortical regions, VGluT3 ${ }^{+} / \mathrm{CB}_{1}{ }^{+} / \mathrm{VIAAT}^{+}$basket cell terminals more or less surrounded pyramidal cell somata. Nevertheless, pyramidal cells having perisomatic DGL $\alpha$ clusters were present at variable frequencies depending on the cortical regions. Pyramidal cells equipped with VGluT3/CB $/$ /DGL $\alpha$ assembly were frequent in the sensorimotor and entorhinal cortices. In the entorhinal cortex, invagination was selectively formed by VGluT3-positive terminals and at DGL $\alpha$ clusters. In contrast, 
perisomatic DGL $\alpha$ clusters were rare in the medial prefrontal cortex and hippocampal CA1, where basket cell terminals expressing both $\mathrm{CB}_{1}$ and VGluT3 construct perisomatic baskets (Somogyi et al., 2004) but did not form DGL $\alpha$ clusters beneath them. In the BLA, we have previously shown that $\mathrm{CB}_{1} / \mathrm{DGL} \alpha$ accumulated invaginating synapses are selective to the BA (Yoshida et al., 2011). In the present study, we found different pyramidal cell populations in the BA, one carrying DGL $\alpha$ clusters and another lacking them, and the absence of VGluT3-expressing GABAergic interneurons and terminals in the LA.

Together, it is conceivable that anatomical invagination is constructed when VGluT3-expressing CCK-positive basket cells innervate pyramidal cell populations that can recruit DGL $\alpha$ to their contact sites and that mechanisms mediating anatomical invagination and DGL $\alpha$ clustering may be differentially working among pyramidal cell populations. Distinct architectures of pyramidal cells differentiating invaginating synapses in the cortical regions and cortex-like amygdala should reflect different properties and requirements for induction, regulatory, and cooperative mechanisms for 2-AG-mediated retrograde signaling in given subregions.

\section{References}

Ali AB, Todorova M (2010) Asynchronous release of GABA via tonic cannabinoid receptor activation at identified interneuron synapses in rat CA1. Eur J Neurosci 31:1196-1207. CrossRef Medline

Azad SC, Monory K, Marsicano G, Cravatt BF, Lutz B, Zieglgänsberger W, Rammes G (2004) Circuitry for associative plasticity in the amygdala involves endocannabinoid signaling. J Neurosci 24:9953-9961. CrossRef Medline

Baude A, Nusser Z, Roberts JD, Mulvihill E, McIlhinney RA, Somogyi P (1993) The metabotropic glutamate receptor $(\mathrm{mGluR} 1 \alpha)$ is concentrated at perisynaptic membrane of neuronal subpopulations as detected by immunogold reaction. Neuron 11:771-787. CrossRef Medline

Belcheva I, Belcheva S, Petkov VV, Petkov VD (1994) Asymmetry in behavioral responses to cholecystokinin microinjected into rat nucleus accumbens and amygdala. Neuropharmacology 33:995-1002. CrossRef Medline

Bisogno T, Howell F, Williams G, Minassi A, Cascio MG, Ligresti A, Matias I, Schiano-Moriello A, Paul P, Williams EJ, Gangadharan U, Hobbs C, Di Marzo V, Doherty P (2003) Cloning of the first snl-DAG lipases points to the spatial and temporal regulation of endocannabinoid signaling in the brain. J Cell Biol 163:463-468. CrossRef Medline

Blankman JL, Cravatt BF (2013) Chemical probes of endocannabinoid metabolism. Pharmacol Rev 65:849-871. CrossRef Medline

Blankman JL, Simon GM, Cravatt BF (2007) A comprehensive profile of brain enzymes that hydrolyze the endocannabinoid 2-arachidonoylglycerol. Chem Biol 14:1347-1356. CrossRef Medline

Chen Q, Nakajima A, Meacham C, Tang YP (2006) Elevated cholecystokininergic tone constitutes an important molecular/neuronal mechanism for the expression of anxiety in the mouse. Proc Natl Acad Sci U S A 103:3881-3886. CrossRef Medline

Chhatwal JP, Gutman AR, Maguschak KA, Bowser ME, Yang Y, Davis M, Ressler KJ (2009) Functional interactions between endocannabinoid and CCK neurotransmitter systems may be critical for extinction learning. Neuropsychopharmacology 34:509-521. CrossRef Medline

Chung L, Moore SD (2009) Cholecystokinin excites interneurons in rat basolateral amygdala. J Neurophysiol 102:272-284. CrossRef Medline

Dinh TP, Carpenter D, Leslie FM, Freund TF, Katona I, Sensi SL, Kathuria S, Piomelli D (2002) Brain monoglyceride lipase participating in endocannabinoid inactivation. Proc Natl Acad Sci U S A 99:10819-10824. CrossRef Medline

Fremeau RT Jr, Burman J, Qureshi T, Tran CH, Proctor J, Johnson J, Zhang H, Sulzer D, Copenhagen DR, Storm-Mathisen J, Reimer RJ, Chaudhry FA, Edwards RH (2002) The identification of vesicular glutamate transporter 3 suggests novel modes of signaling by glutamate. Proc Natl Acad Sci U S A 99:14488-14493. CrossRef Medline
Freund TF (2003) Interneuron Diversity series: rhythm and mood in perisomatic inhibition. Trends Neurosci 26:489-495. CrossRef Medline

Fukudome Y, Ohno-Shosaku T, Matsui M, Omori Y, Fukaya M, Tsubokawa H,Taketo MM, Watanabe M, Manabe T, Kano M (2004) Two distinct classes of muscarinic action on hippoccampal inhibitory synapses: M2mediated direct suppression and M1/M3-mediated indirect suppression through endocannabinoid signaling. Eur J Neurosci 19:2682-2692. CrossRef Medline

Gao Y, Vasilyev DV, Goncalves MB, Howell FV, Hobbs C, Reisenberg M, Shen R, Zhang MY, Strassle BW, Lu P, Mark L, Piesla MJ, Deng K, Kouranova EV, Ring RH, Whiteside GT, Bates B, Walsh FS, Williams G, Pangalos MN, Samad TA, Doherty P (2010) Loss of retrograde endocannabinoid signaling and reduced adult neurogenesis in diacylglycerol lipase knock-out mice. J Neurosci 30:2017-2024. CrossRef Medline

Gras C, Herzog E, Bellenchi GC, Bernard V, Ravassard P, Pohl M, Gasnier B, Giros B, El Mestikawy S (2002) A third vesicular glutamate transporter expressed by cholinergic and serotoninergic neurons. J Neurosci 22:54425451. Medline

Gulyas AI, Cravatt BF, Bracey MH, Dinh TP, Piomelli D, Boscia F, Freund TF (2004) Segregation of two endocannabinoid-hydrolyzing enzymes into pre- and postsynaptic compartments in the rat hippocampus, cerebellum and amygdala. Eur J Neurosci 20:441-458. CrossRef Medline

Hashimotodani Y, Ohno-Shosaku T, Tsubokawa H, Ogata H, Emoto K, Maejima T, Araishi K, Shin HS, Kano M (2005) Phospholipase Cbeta serves as a coincidence detector through its $\mathrm{Ca}^{2+}$ dependency for triggering retrograde endocannabinoid signal. Neuron 45:257-268. CrossRef Medline

Hashimotodani Y, Ohno-Shosaku T, Kano M (2007a) Endocannabinoids and synaptic function in the CNS. Neuroscientist 13:127-137. CrossRef Medline

Hashimotodani Y, Ohno-Shosaku T, Kano M (2007b) Presynaptic monoacylglycerol lipase activity determines basal endocannabinoid tone and terminates retrograde endocannabinoid signaling in the hippocampus. J Neurosci 27:1211-1219. CrossRef Medline

Hashimotodani Y, Ohno-Shosaku T, Kano M (2007c) $\mathrm{Ca}^{2+}$-assisted receptor-driven endocannabinoid release: mechanisms that associate presynaptic and postsynaptic activities. Curr Opin Neurobiol 17:360365. CrossRef Medline

Herzog E, Gilchrist J, Gras C, Muzerelle A, Ravassard P, Giros B, Gaspar P, El Mestikawy S (2004) Localization of VGLUT3, the vesicular glutamate transporter type 3, in the rat brain. Neuroscience 123:983-1002. CrossRef Medline

Higley MJ, Gittis AH, Oldenburg IA, Balthasar N, Seal RP, Edwards RH, Lowell BB, Kreitzer AC, Sabatini BL (2011) Cholinergic interneurons mediate fast VGluT3-dependent glutamatergic transmission in the striatum. PLoS One 6:e19155. CrossRef Medline

Honda T, Wada E, Battey JF, Wank SA (1993) Differential gene expression of $\mathrm{CCK}(\mathrm{A})$ and $\mathrm{CCK}(\mathrm{B})$ receptors in the rat brain. Mol Cell Neurosci 4:143-154. CrossRef Medline

Ichikawa R, Yamasaki M, Miyazaki T, Konno K, Hashimoto K, Tatsumi H, Inoue Y, Kano M, Watanabe M (2011) Developmental switching of perisomatic innervation from climbing fibers to basket cell fibers in cerebellar Purkinje cells. J Neurosci 31:16916-16927. CrossRef Medline

Kano M, Ohno-Shosaku T, Hashimotodani Y, Uchigashima M, Watanabe M (2009) Endocannabinoid-mediated control of synaptic transmission. Physiol Rev 89:309-380. CrossRef Medline

Katona I, Sperlágh B, Sík A, Käfalvi A, Vizi ES, Mackie K, Freund TF (1999) Presynaptically located $\mathrm{CB} 1$ cannabinoid receptors regulate GABA release from axon terminals of specific hippocampal interneurons. J Neurosci 19:4544-4558. Medline

Katona I, Rancz EA, Acsady L, Ledent C, Mackie K, Hajos N, Freund TF (2001) Distribution of CB1 cannabinoid receptors in the amygdala and their role in the control of GABAergic transmission. J Neurosci 21:95069518. Medline

Katona I, Urbán GM, Wallace M, Ledent C, Jung KM, Piomelli D, Mackie K, Freund TF (2006) Molecular composition of the endocannabinoid system at glutamatergic synapses. J Neurosci 26:5628-5637. CrossRef Medline

Kawamura Y, Fukaya M, Maejima T, Yoshida T, Miura E, Watanabe M, Ohno-Shosaku T, Kano M (2006) The CB1 cannabinoid receptor is the major cannabinoid receptor at excitatory presynaptic sites in the hippocampus and cerebellum. J Neurosci 26:2991-3001. CrossRef Medline 
Kennedy JL, Bradwejn J, Koszycki D, King N, Crowe R, Vincent J, Fourie O (1999) Investigation of cholecystokinin system genes in panic disorder. Mol Psychiatry 4:284-285. CrossRef Medline

Klausberger T, Somogyi P (2008) Neuronal diversity and temporal dynamics: the unity of hippocampal circuit operations. Science 321:53-57. CrossRef Medline

Kreitzer AC, Regehr WG (2001) Retrograde inhibition of presynaptic calcium influx by endogenous cannabinoids at excitatory synapses onto Purkinje cells. Neuron 29:717-727. CrossRef Medline

Larsson LI, Rehfeld JF (1979) Localization and molecular heterogeneity of cholecystokinin in the central and peripheral nervous system. Brain Res 165:201-218. CrossRef Medline

Lasztóczi B, Tukker JJ, Somogyi P, Klausberger T (2011) Terminal field and firing selectivity of cholecystokinin-expressing interneurons in the hippocampal CA3 area. J Neurosci 31:18073-18093. CrossRef Medline

Lee SH, Földy C, Soltesz I (2010) Distinct endocannabinoid control of GABA release at perisomatic and dendritic synapses in the hippocampus. J Neurosci 30:7993-8000. CrossRef Medline

Losonczy A, Biró AA, Nusser Z (2004) Persistently active cannabinoid receptors mute a subpopulation of hippocampal interneurons. Proc Natl Acad Sci U S A 101:1362-1367. CrossRef Medline

Lujan R, Nusser Z, Roberts JD, Shigemoto R, Somogyi P (1996) Perisynaptic location of metabotropic glutamate receptors mGluR1 and mGluR5 on dendrites and dendritic spines in the rat hippocampus. Eur J Neurosci 8:1488-1500. CrossRef Medline

Maejima T, Hashimoto K, Yoshida T, Aiba A, Kano M (2001) Presynaptic inhibition caused by retrograde signal from metabotropic glutamate to cannabinoid receptors. Neuron 31:463-475. CrossRef Medline

Maejima T, Oka S, Hashimotodani Y, Ohno-Shosaku T, Aiba A, Wu D, Waku K, Sugiura T, Kano M (2005) Synaptically driven endocannabinoid release requires $\mathrm{Ca}^{2+}$-assisted metabotropic glutamate receptor subtype 1 to phospholipase $\mathrm{C} \beta 4$ signaling cascade in the cerebellum. J Neurosci 25:6826-6835. CrossRef Medline

Marsicano G, Lutz B (1999) Expression of the cannabinoid receptor CB1 in distinct neuronal subpopulations in the adult mouse forebrain. Eur J Neurosci 11:4213-4225. CrossRef Medline

Marsicano G, Wotjak CT, Azad SC, Bisogno T, Rammes G, Cascio MG, Hermann H, Tang J, Hofmann C, Zieglgänsberger W, Di Marzo V, Lutz B (2002) The endogenous cannabinoid system controls extinction of aversive memories. Nature 418:530-534. CrossRef Medline

Mascagni F, McDonald AJ (2003) Immunohistochemical characterization of cholecystokinin containing neurons in the rat basolateral amygdala. Brain Res 976:171-184. CrossRef Medline

Matsuda LA, Bonner TI, Lolait SJ (1993) Localization of cannabinoid receptor mRNA in rat brain. J Comp Neurol 327:535-550. CrossRef Medline

McDonald AJ, Mascagni F (2001) Localization of the CB1 type cannabinoid receptor in the rat basolateral amygdala: high concentrations in a subpopulation of cholecystokinin-containing interneurons. Neuroscience 107: 641-652. CrossRef Medline

Mechoulam R, Ben-Shabat S, Hanus L, Ligumsky M, Kaminski NE, Schatz AR, Gopher A, Almog S, Martin BR, Compton DR (1995) Identification of an endogenous 2-monoglyceride, present in canine gut, that binds to cannabinoid receptors. Biochem Pharmacol 50:83-90. CrossRef Medline

Meis S, Munsch T, Sosulina L, Pape HC (2007) Postsynaptic mechanisms underlying responsiveness of amygdaloid neurons to cholecystokinin are mediated by a transient receptor potential-like current. Mol Cell Neurosci 35:356-367. CrossRef Medline

Miura E, Fukaya M, Sato T, Sugihara K, Asano M, Yoshioka K, Watanabe M (2006) Expression and distribution of JNK/SAPK-associated scaffold protein JSAP1 in developing and adult mouse brain. J Neurochem 97: 1431-1446. CrossRef Medline

Nelson AB, Bussert TG, Kreitzer AC, Seal RP (2014) Striatal cholinergic neurotransmission requires VGLUT3. J Neurosci 34:8772-8777. CrossRef Medline

Noh J, Seal RP, Garver JA, Edwards RH, Kandler K (2010) Glutamate corelease at GABA/glycinergic synapses is crucial for the refinement of an inhibitory map. Nat Neurosci 13:232-238. CrossRef Medline

Ohno-Shosaku T, Maejima T, Kano M (2001) Endogenous cannabinoids mediate retrograde signals from depolarized postsynaptic neurons to presynaptic terminals. Neuron 29:729-738. CrossRef Medline

Ohno-Shosaku T, Shosaku J, Tsubokawa H, Kano M (2002) Cooperative endocannabinoid production by neuronal depolarization and group I metabotropic glutamate receptor activation. Eur J Neurosci 15:953-961. CrossRef Medline

Pan B, Wang W, Long JZ, Sun D, Hillard CJ, Cravatt BF, Liu QS (2009) Blockade of 2-arachidonoylglycerol hydrolysis by selective monoacylglycerol lipase inhibitor 4-nitrophenyl 4-(dibenzo[d] [1,3] dioxol-5-yl(hydroxy)methyl)piperidine-1carboxylate (JZL184) enhances retrograde endocannabinoid signaling. J Pharmacol Exp Ther 331:591-597. CrossRef Medline

Robbe D, Montgomery SM, Thome A, Rueda-Orozco PE, McNaughton BL, Buzsaki G (2006) Cannabinoids reveal importance of spike timing coordination in hippocampal function. Nat Neurosci 9:1526-1533. CrossRef Medline

Schäfer MK, Varoqui H, Defamie N, Weihe E, Erickson JD (2002) Molecular cloning and functional identification of mouse vesicular glutamate transporter 3 and its expression in subsets of novel excitatory neurons. J Biol Chem 277:50734-50748. CrossRef Medline

Schlosburg JE, Blankman JL, Long JZ, Nomura DK, Pan B, Kinsey SG, Nguyen PT, Ramesh D, Booker L, Burston JJ, Thomas EA, Selley DE, Sim-Selley LJ, Liu QS, Lichtman AH, Cravatt BF (2010) Chronic monoacylglycerol lipase blockade causes functional antagonism of the endocannabinoid system. Nat Neurosci 13:1113-1119. CrossRef Medline

Sheinin A, Talani G, Davis MI, Lovinger DM (2008) Endocannabinoid-and mGluR5-dependent short-term synaptic depression in an isolated neuron/bouton preparation from the hippocampal CA1 region. J Neurophysiol 100:1041-1052. CrossRef Medline

Somogyi J, Baude A, Omori Y, Shimizu H, El Mestikawy S, Fukaya M, Shigemoto R,Watanabe M, Somogyi P (2004) GABAergic basket cells expressing cholecystokinin contain vesicular glutamate transporter type 3 (VGLUT3) in their synaptic terminals in hippocampus and isocortex of the rat. Eur J Neurosci 19:552-569. CrossRef Medline

Stella N, Schweitzer P, Piomelli D (1997) A second endogenous cannabinoid that modulates long-term potentiation. Nature 388:773-778. CrossRef Medline

Sugiura T, Kondo S, Sukagawa A, Nakane S, Shinoda A, Itoh K, Yamashita A, Waku K (1995) 2-Arachidonoylglycerol: a possible endogenous cannabinoid receptor ligand in brain. Biochem Biophys Res Commun 215:89-97. CrossRef Medline

Tanimura A, Yamazaki M, Hashimotodani Y, Uchigashima M, Kawata S, Abe M, Kita Y, Hashimoto K, Shimizu T, Watanabe M, Sakimura K, Kano M (2010) The endocannabinoid 2-arachidonoylglycerol produced by diacylglycerol lipase alpha mediates retrograde suppression of synaptic transmission. Neuron 65:320-327. CrossRef Medline

Tanimura A, Uchigashima M, Yamazaki M, Uesaka N, Mikuni T, Abe M, Hashimoto K, Watanabe M, Sakimura K, Kano M (2012) Synapse type-independent degradation of the endocannabinoid 2-arachidonoylglycerol after retrograde synaptic suppression. Proc Natl Acad Sci U S A 109:12195-12200. CrossRef Medline

Tsou K, Mackie K, Sañudo-Peña MC, Walker JM (1999) Cannabinoid CB1 receptors are localized primarily on cholecystokinin-containing GABAergic interneurons in the rat hippocampal formation. Neuroscience 93: 969-975. CrossRef Medline

Uchigashima M, Narushima M, Fukaya M, Katona I, Kano M, Watanabe M (2007) Subcellular arrangement of molecules for 2-arachidonoylglycerol-mediated retrograde signaling and its physiological contribution to synaptic modulation in the striatum. J Neurosci 27:3663-3676. CrossRef Medline

Uchigashima M, Yamazaki M, Yamasaki M, Tanimura A, Sakimura K, Kano M, Watanabe M (2011) Molecular and morphological configuration for 2-arachidonoylglycerol-mediated retrograde signaling at mossy cellgranule cell synapses in the dentate gyrus. J Neurosci 31:7700-7714. CrossRef Medline

Vanderhaeghen J, Goldman S, Lotstra F, Van Reeth O, Deschepper C, Rossier J, Schiffmann S (1985) Co-existence of cholecystokinin- or gastrin-like peptides with other peptides in the hypophysis and the hypothalamus. Ann N Y Acad Sci 448:334-344. CrossRef Medline

Varga V, Losonczy A, Zemelman BV, Borhegyi Z, Nyiri G, Domonkos A, Hangya B, Holderith N, Magee JC, Freund TF (2009) Fast synaptic subcortical control of hippocampal circuits. Science 326:449-453. CrossRef Medline

Varma N, Carlson GC, Ledent C, Alger BE (2001) Metabotropic glutamate receptors drive the endocannabinoid system in hippocampus. J Neurosci 21:RC188. Medline 
Wilson RI, Nicoll RA (2001) Endogenous cannabinoids mediate retrograde signalling at hippocampal synapses. Nature 410:588-592. CrossRef Medline

Yamasaki M, Matsui M, Watanabe M (2010) Preferential localization of muscarinic M1 receptor on dendritic shaft and spine of cortical pyramidal cells and its anatomical evidence for volume transmission. J Neurosci 30:4408-4418. CrossRef Medline

Yamazaki M, Fukaya M, Hashimoto K, Yamasaki M, Tsujita M, Itakura M, Abe M, Natsume R, Takahashi M, Kano M, Sakimura K, Watanabe M (2010) TARPs $\gamma-2$ and $\gamma-7$ are essential for AMPA receptor expression in the cerebellum. Eur J Neurosci 31:2204-2220. CrossRef Medline

Yoshida T, Fukaya M, Uchigashima M, Miura E, Kamiya H, Kano M, Wa- tanabe M (2006) Localization of diacylglycerol lipase- $\alpha$ around postsynaptic spine suggests close proximity between production site of an endocannabinoid, 2-arachidonoyl-glycerol, and presynaptic cannabinoid CB1 receptor. J Neurosci 26:4740 - 4751. CrossRef Medline

Yoshida T, Uchigashima M, Yamasaki M, Katona I, Yamazaki M, Sakimura K, Kano M, Yoshioka M, Watanabe M (2011) Unique inhibitory synapse with particularly rich endocannabinoid signaling machinery on pyramidal neurons in basal amygdaloid nucleus. Proc Natl Acad Sci U S A 108: 3059-3064. CrossRef Medline

Zhu PJ, Lovinger DM (2005) Retrograde endocannabinoid signaling in a postsynaptic neuron/synaptic bouton preparation from basolateral amygdala. J Neurosci 25:6199-6207. CrossRef Medline 